\title{
Fiscal policy and the development of green transportation infrastructure: the case of China's high-speed railways
}

\author{
Zoey Wong ${ }^{1} \cdot$ Afei Chen ${ }^{2} \cdot$ Chenrong Shen ${ }^{2} \cdot$ Dailong Wu ${ }^{3}$
}

Received: 2 August 2021 / Accepted: 20 December 2021 / Published online: 10 February 2022

(c) The Author(s), under exclusive licence to Springer Science+Business Media, LLC, part of Springer Nature 2022

\begin{abstract}
High-speed rail (HSR) has been highly valued as an accelerator of green economic growth. However, the difficulty in financing caused by the high investment demand and long construction cycle of high-speed rail is an ongoing dilemma facing the high-speed rail industry. Using data from Chinese cities from 2003 to 2018, this paper explores whether fiscal policy is conducive to solving financing problems for high-speed railway construction. At the same time, this paper investigates the economic and environmental benefits of high-speed rail construction investment for urban development. We find that fiscal policy helps reduce the financing cost of high-speed railway construction projects and attracts social capital, spurring investment in high-speed rail construction. When economic policy uncertainty rises, companies will choose more secure, "safe" investments to avoid potential risks, such as government-led high-speed rail construction projects, which has led to their further expansion. Regarding its economic effect, high-speed rail construction investment directly promotes urban productivity, investment scale, and industrial structure upgrades. Over the long term, investment in HSR construction helps curb urban pollutant emissions, thus contributing to urban eco-efficiency.
\end{abstract}

Keywords Fiscal policy $\cdot$ High-speed rail $\cdot$ Economic policy uncertainty $\cdot$ Economic effects $\cdot$ Environmental effects

Dailong Wu

wud12021@163.com

1 School of Business, Nanjing University, Nanjing 210093, China

2 School of Industrial Development, Nanjing University of Finance \& Economics, Nanjing 210003, China

3 School of Business, Nanjing Normal University, Nanjing 210023, China 


\section{Introduction}

Transportation infrastructure is fundamental to national economic and social development, linking various regions and economic sectors. It plays a vital role in supporting and guaranteeing economic development and social progress. However, for many years, China's transportation infrastructure has lagged behind the requirements of economic development. The government has invested heavily in transportation infrastructure facilities while adhering to the principle of moderate advancement. In particular, the government has attached great importance to planning and investment in the high-speed rail (HSR) industry. In 2004, 2008, and 2016, the State Railway Administration of China promulgated the Medium- and Long-term Railway Network Plan. In 2016, the westernmost section of the Shanghai-Kunming highspeed railway-the Guizhou-Yunnan section-realized the "Yunnan-Guizhou" hand in hand, and the entire Shanghai-Kunming high-speed railway line was completed. At this moment, China's high-speed "four vertical and four horizontal" rail transportation network was accomplished (Jiang et al. 2017).

In 2019, the Outline for the Construction of a Strong Transportation Country ${ }^{1}$ stated that China should, as soon as possible, actively guide and collaborate in the development of fast intercity railroads, fast trunk railroads, urban (suburban) fast railroads, and urban rail transit networks, and promote the construction of an international urban cluster rail transit network with two integrations. Data show that by the end of 2020, China's high-speed railroad operating mileage has reached $146,300 \mathrm{~km}$, including 38,000 km of high-speed railroads. ${ }^{2}$ Railroad construction has made historic achievements and played an important supporting role for economic and social development. The Chinese government attaches great importance to the investment, planning, and construction of high-speed railroads. Accelerating their construction is an important means to solve the fundamental dilemma of China's backward transportation infrastructure and an essential link in the process of China's high-quality economic development.

Fiscal policy is one of the core tools of national macro-control. The Central Economic Conference in December 2019 emphasized once and for all the critical role of fiscal policy in keeping the economy running smoothly. ${ }^{3}$ Therefore, the investment and construction of high-speed railroads are inseparable from the strong support of fiscal policy. Fiscal policy plays a crucial role in promoting green economic development. On the one hand, the government can increase fiscal expenditures on environmental protection and green infrastructure investment, reducing the challenges of green investment and thus improving the efficiency of green credit allocation (Wei and Cao 2019). On the other hand, the government can collect environmental taxes through taxation policies and create tax incentives and other means to guide the flow of capital, talent, and technology to the low-carbon economy through

\footnotetext{
${ }^{1}$ For details, see: http://www.gov.cn/zhengce/2019-09/19/content_5431432.htm.

2 Drawn from China Railway Statistical Bulletin 2020.

3 After the financial crisis in 2008, China's economy was able to continue running smoothly precisely because of strong national fiscal policy support.
} 
the competitive mechanism of the market (Chu 2018; Zheng 2017), thus promoting the green and low-carbon development of the economy. Therefore, achieving a green economic recovery in the post-COVID-19 era requires the active role of the government.

However, the implementation of China's fiscal policy is currently under severe pressure. Specifically, the debt problem accumulated from the " 4 trillion" fiscal stimulus plan introduced in response to the global economic crisis has made subsequent funding challenging to obtain. At the same time, China is in a critical period-economic growth is shifting from high speed to high quality (Kong et al. 2021a, b; Zhang et al. 2017a, b, c, 2021; Zhang and Xue 2020), and an active fiscal policy is needed to escort economic growth (Zhang et al. 2020). The pressure of debt and transformation has made "do not waste a penny"4 one of the principles for the Chinese government's rational and efficient use of fiscal funds. Consequently, can the use of monetary funds in the form of investments in transportation infrastructure construction result in a win-win situation for economic growth and environmental protection? Is it conducive to promoting industrial transformation and green development? Further, will the changing external environment, such as economic policy uncertainty and marketization, reduce the efficiency of such funds and ultimately hamper the effectiveness of fiscal policy implementation? How do regions at different development levels plan their fiscal approach toward high-speed rail construction?

At present, high-speed railroad projects financed by government investment are on the fast track. Based on the perspective of green infrastructure construction, this paper explores the impact effect of fiscal policy on high-speed railway investment and construction through a theoretical explanation and empirical analysis. It uses the 2013 "Opinions of the State Council on Reforming the Railway Investment and Financing System to Accelerate Railway Construction" as the node of fiscal policy implementation to discern the effect of fiscal policy on investment in high-speed rail construction. At the same time, this paper evaluates the economic and environmental effects of investments in high-speed rail construction to provide targeted policy recommendations on how developing countries can plan for green infrastructure development.

Judging the economic benefits of high-speed railroads is of great concern for academics. Compared with existing studies, the contributions of this paper are mainly in the following two aspects. First, most existing studies on investment in HSR construction have focused on industrial clustering (Deng et al. 2017; Fritsch et al. 2011), economic growth (Ahlfeldt et al. 2018; Jia et al. 2017; Liu and Li 2017), and the shaping of spatial layout (Wang and Ni 2016; Zhang et al. 2018). Although a few scholars have also started to pay attention to the investment and financing of high-speed railway construction, most are concerned with the economic benefits of investment in high-speed railway construction (Han et al. 2012; Jiang et al. 2017). From the perspective of the effectiveness of fiscal policy implementation, this paper empirically examines the impact of fiscal policy on investment in high-speed railway

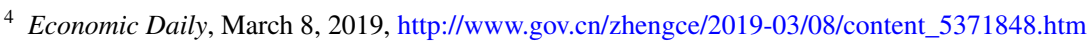


construction, as represented by the 2013 "State Council Opinions on Reforming the Railway Investment and Financing System to Speed Up Railway Construction." This approach enriches the research related to the investment and construction of green transportation infrastructure. Moreover, this paper introduces economic policy uncertainty, degree of marketization, urban characteristics, and geographic location in an attempt to analyze how external environmental characteristics affect the relationship between fiscal policy and investment in HSR construction to target policy recommendations for planning green infrastructure development in developing countries.

Second, the existing literature is inconclusive about the relationship between investment in HSR construction and economic growth, and significantly less attention has been paid to the economic performance of investments in HSR construction. The investment in and construction of high-speed rail in China have been questioned in many ways, including the economic efficiency of high-speed rail projects, debt risk issues, and safety issues (Nash 2015; Wu et al. 2014; Zhuang and Hou 2012). Based on the relationship between fiscal policy and HSR construction investment, this paper analyzes the dual economic and environmental impacts of HSR construction investment in terms of long-term and short-term effects. It is found that the investment in high-speed railway construction directly contributes to the improvement of urban productivity, the expansion of investment scale, and the upgrading of industrial sector. In terms of environmental effects, investing in HSR construction contributes to the longterm suppression of urban pollutant emissions, thus promoting urban eco-efficiency. This finding can help developing countries better understand the "appropriateness" of transportation infrastructure investment and rationally plan the investment scale and construction of inter-regional high-speed rail lines.

The rest of the paper is structured as follows: Sect. 2 outlines the theoretical analysis and provides the research hypotheses to be tested in the following empirical analysis; Sect. 3 constructs an econometric model to explain the data sources and variable measurements; Sect. 4 empirically analyzes the relationship between fiscal policy implementation and investment in high-speed rail construction; Sect. 5 discusses the economic and environmental effects brought about by investment in high-speed rail construction; Sect. 6 sorts out the research findings and makes policy recommendations.

\section{Theoretical analysis and hypothesis development}

Transportation infrastructure investment is one of the central channels through which the government can stabilize growth. The government mainly invests in transportation infrastructure because of its strong externalities, public product attributes, and economies of scale (Liu and Li 2020). Since most of the funds for transportation infrastructure investment come from broad-based financing sources (Zhang et al. 2019), when the economy faces a downturn, the government increases fiscal spending and expands transportation infrastructure investment to stabilize economic growth (Wang 2020). As an important transportation infrastructure sector that drives economic growth, high-speed railroads play an 
increasingly essential role in serving the overall economic and social development. As a basic and pioneering service industry, railroad transportation is of great significance to the overall economic efficiency improvement in China. However, the investment demand for railroad construction is substantial, and the construction cycle is long, so all parties are highly concerned about the railroad industry's reform and development.

High-speed railroad transportation has evident quasi-public product characteristics, and high-speed railroad construction requires massive levels of investment. It is difficult for general commercial enterprises to bear the pressure of investment recovery. For a long time, the railroad industry has had institutional characteristics that unite government and enterprises, deriving railroad construction funds from financial allocations and bank loans. With the deepening of reform, the sources of railroad investment have been enriched, and a diversified investment and financing system now includes domestic bank loans, state budget funds, special funds, foreign loans, and social financing. At present, the source of funds for China's railroad construction is still mainly domestic bank loans. However, the continuous development of the railroad industry requires a large amount of new investment. If the investment and financing structure has not been optimized, relying heavily on state-owned bank loans will further aggravate the financial risk (Wong et al. 2021; Zhang and Guo 2019).

In order to solve the problems of insufficient competition, low efficiency, and financing difficulties in the railroad industry, introducing external capital and accelerating the reform of the investment and financing system are critical elements of railroad industry reform. In 2012, China's Ministry of Railways issued the "Opinions on the Implementation of Encouraging and Guiding Private Capital Investment in Railways" and began to gradually explore the introduction of social capital in all aspects of the railroad industry chain. In 2013, the "Opinions on Reforming the Railway Investment and Financing System to Speed Up Railway Construction" put forward the general idea of "fully opening up the railroad construction market and implementing classified investment and construction for new railroads." In 2014, the "Measures for the Management of Railway Development Fund" clarified the investment fund construction program in railroad industry development. In 2015, the "Implementation Opinions on Further Encouraging and Expanding Social Capital Investment and Construction of Railways" proposed fully opening the railroad investment and operation market and promoting the diversification of investment and financing methods.

To date, the railroad industry has been opened up to social capital from the construction field and transportation field to all fields. All restrictions on social capital entering the railroad industry were removed from the policy. In 2016, the "Opinions on Deepening the Reform of the Investment and Financing System" further emphasized the need to strengthen government and social capital cooperation in railroad infrastructure and vigorously develop direct financing. From the above analysis, it can be seen that a series of policy documents on the railroad investment and financing system help to reasonably guide social capital and government capital into high-speed railroad construction, reduce the financing cost of high-speed railroad construction projects and create a welcoming institutional 
environment for the investment and development of the high-speed railroad industry. Consequently, this paper proposes the following research hypothesis:

Hypothesis 1 Fiscal policy helps reduce the financing cost of high-speed railway construction projects and expands the scale of investment in high-speed railway construction.

As the Chinese government is vigorously developing and building high-speed rail networks, it is of great practical importance to comprehensively assess the impact of China's high-speed rail construction investment on the national economy and the environment. The economic effects of high-speed rail transportation in China and abroad demonstrate that it clearly serves as a good tool for connecting cities. High-speed rail transportation can efficiently promote economic exchanges between cities and allow interested parties to communicate, learn advanced technology, and gain management experience. It can also promote the flow of population and labor between cities, reduce the loss of frictional unemployment, and promote regional integration and high-quality urban economic growth.

In fact, the value of high-speed rail is mainly reflected in providing people with a convenient means of access, which is essentially a means of passenger transportation. Furthermore, there is a corresponding cost to traveling by high-speed rail, which is greater than a regular train or car. However, high-speed rail passenger transportation saves people a lot of time on the road. For passengers with high time costs, choosing high-speed rail travel is a relatively better option (Sun and Huang, 2019). From this perspective, the opening of high-speed rail can stimulate people to "go out" and encourage other cities to "come in," thus promoting the flow of talent between cities. Through the flow of people, the exchange and communication between cities are strengthened, and the learning and cooperation of enterprises between cities are enhanced so that the innovation ability and technology level of enterprises improve (Kong et al. 2021f).

From a spatial perspective, Bai and Jiang (2015) argue that spatial correlation in the quality of urban economic growth is due to the factor mobility between cities. The authors state that the opening of high-speed rail helps promote the factor flow between cities so that factors are distributed in different cities according to demand. Cities with high-speed rail will have faster factor mobility due to the advantage of more convenient transportation (Cheng et al. 2020; Kong et al. 2021c, g). In addition, high-speed rail will also affect local government policies. The openness of the city increases, and the government can actively promote investment and implement preferential policies to attract enterprises, thus encouraging industrial agglomeration (Kong et al. 2020, 2021d; Zhang and Vigne 2021). Based on this finding, this paper proposes the following:

Hypothesis 2 Investment in high-speed rail construction can reduce the cost of intercity factor mobility and information asymmetry, bring a large amount of highquality investment, move the development of industrial infrastructure toward rationalization and advancement, and improve urban production efficiency. 
While investment in high-speed rail construction can positively impact the economy and employment, it can also affect the environment. The raw materials involved in the construction of HSR, such as cement and steel, come from high-energy-consuming production sectors, and construction will inevitably result in more significant emissions (Jiang et al. 2017). Akerman (2011) finds in a study of high-speed rail in Europe that although high-speed rail reduces GHG emissions during operation, due to the extensive implicit emissions of raw materials during the construction period, the final result may not significantly reduce emissions. However, as a current transportation mode, HSR is inherently green, environmentally friendly, and efficient (Chester 2014). High-speed rail is also one of the major influences on urban green development, with a significant impact on urban green finance and green productivity (Kong et al. 2021e). Compared with 2019, national railroads in 2020 can cause a $5.3 \%$ decrease in consumption of converted standard coal, $5.6 \%$ decrease in chemical oxygen demand emissions, and $38.1 \%$ decrease in carbon dioxide emissions, ${ }^{5}$ which plays an essential role in continuing to promote pollution prevention and control and win the battle in favor of the environment.

On the one hand, high-speed rail will enable travelers to change their original mode of transportation and reduce environmental pollution. For example, replacing traditional railroads with the Wuhan-Guangzhou high-speed railway has reduced $\mathrm{CO}_{2}$ emissions by 2341.7 million tons per year (Zhang 2011). On the other hand, substituting traditional transportation modes (e.g., cars) can also effectively reduce environmental pollution (Liang and Xi 2016). The ability of rail transportation to reduce air pollution is mainly reflected in the fact that, on average, per passenger $\mathrm{CO}_{2}$ emissions from rail transportation are about $1 / 25$ of that from automobiles (Zheng et al. 2013). At the city level, rail transit helps reduce carbon monoxide emissions from automobile exhaust (Chen and Whalley 2012). Therefore, comprehensively assessing the impact of high-speed railway construction investment on the economy, employment, and the environment is crucial for China's future under the synergistic development of population and economic environment. Based on the above analysis, this paper proposes the following:

Hypothesis 3 Investment in high-speed rail construction can reduce urban pollutant emissions and promote the construction of green production systems in cities.

\section{Research design}

\subsection{Data sources and variable descriptions}

\subsubsection{Core variables}

This paper examines the impact of fiscal policy on investments in high-speed railroad construction in China, using a sample of Chinese cities at the prefecture level

\footnotetext{
5 Data drawn from the China Railway Statistical Bulletin 2020.
} 
and above from 2003-2018. Fiscal policy is the core explanatory variable of this paper. The 2013 "Opinions of the State Council on Reforming the Railway Investment and Financing System to Speed Up Railway Construction"6 is used as the policy shock event. The opinion is a guiding opinion to ensure the smooth progress of railroad projects under construction, the timely completion of projects in operation, and the full realization of the development goals of the 12th Five-Year Plan. Investment in high-speed railway construction is the explanatory variable in this paper, and the number of high-speed railway stations is used to measure investment in highspeed railway construction. The data of HSR stations are mainly obtained from the textual information contained in the Special Issue on Railway Passenger and Freight Transportation, China Railway Yearbook, China Railway Corporation website, ${ }^{7}$ and State Railway Administration of the People's Republic of China. ${ }^{8}$ Through manual collation, this paper finally obtained 2,640 high-speed railway station samples.

In 2003, China's high-speed railroad established the basic idea of the "technology market" and cooperated with foreign enterprises to construct and develop China's high-speed railway technology. China's high-speed railroad then began to move from the "exploration and experimentation stage" to the "development and maturity stage." By 2018, China had built a high-density, high-speed railroad network in the Yangtze River Delta, the Pearl River Delta, the Bohai Sea, and other city clusters and completed high-speed railway interconnection among four major segments in the eastern, central, western, and northeastern regions. Therefore, the sample time selected in this paper spans 2003-2018.

\subsubsection{Control variables}

The control variables in this paper are mainly city-level variables, including the level of informatization ( Inf), the degree of government intervention (Gov), the level of openness to the outside world (Open), transportation infrastructure (Tr), per capita GDP $(P g d p)$, and human capital $(H c)$. Among them, the level of informatization (Inf) is measured by averaging the share of the total regional telecommunication services and the average of total national telecommunication services. The degree of government intervention (Gov) is expressed using the ratio of local fiscal expenditure to regional GDP, as proposed by Guo et al. (2020). The level of openness to the outside world (Open) is expressed by the ratio of the amount of actual foreign investment used in the year to regional GDP, as discussed by Lin and Meng (2021). Transportation infrastructure (Tr) is expressed following Shao and Yang (2010), who use urban road area per capita as a measurement. GDP per capita $(P g d p)$ represents the degree of economic development of the city. Human capital $(H c)$ is measured using the ratio of the number of students enrolled in regional general higher education to the total regional population, drawing on the methodology of Zhu et al. (2011).

\footnotetext{
6 "Opinions of the State Council on Reforming the Railway Investment and Financing System to Accelerate Railway Construction." See http://www.gov.cn/zwgk/.

7 China Railway Corporation website: http://www.china-railway.com.cn/.

8 State Railway Administration of the People's Republic of China: http://www.nra.gov.cn/.
} 
The city-level data used in this paper come from the China Urban Statistical Yearbook, the China Regional Statistical Yearbook, and the EPS database. Considering the validity of the sample data, the sample of cities with incomplete information and missing key data were excluded from this paper. We also excluded any places that changed from prefecture-level cities to county-level cities within the sample period. We finally screened out 4,576 city-annual observations. Further, this paper adopts a linear interpolation method, a mean method, and a smoothing method to supplement some cities with missing data.

\subsubsection{Other variables}

This paper constructs an economic policy uncertainty index (EPU) for China, drawing on Baker's (2016) methodology. First, we calculated the proportion of daily news articles in the South China Morning Post in Hong Kong, China, that contain the keywords "China," "economy," "policy," and "uncertainty" to the total number of articles in that month. We then built the China Economic Policy Uncertainty Index (EPU Index) by combining the Global Economic Policy Uncertainty Index data published on the Economic Policy Uncertainty website. ${ }^{9}$ The EPU index is not a single indicator but a comprehensive figure composed of multiple indicators. In this paper, we draw on the method of Fan et al. (2003) to construct the index system of marketization degree from six aspects: the relationship between government and market, the degree of product market development, the development of the non-state economy, the degree of factor market development, the degree of perfect market services, and the degree of intellectual property protection. We calculate the weights of each basic index by principal component analysis and finally obtain the city marketization degree and annual composite score.

\subsection{Methodology}

This paper conducts a quasi-natural experiment using the 2013 "Opinions of the State Council on Reforming the Railway Investment and Financing System to Accelerate Railway Construction" as the policy shock event, with the years affected by the policy as the treatment group and the years unaffected by the policy as the control group. Given that the double-difference method is a traditional method for assessing policy effects (Zhou and Chen 2005), it can effectively combine the "before and after differences" and "with and without differences" of the policy, complementing the "natural experiment," which is not entirely randomized in terms of sample allocation. Consequently, this method can obtain a realistic assessment of the intervention effects. In this paper, we construct a double-difference model to study the effect of fiscal policy on investment in urban high-speed rail construction by referring to the studies of Heckman et al. (1985, 1986), Card (1990), and Puhani (2000). The model is shown in Eq. (1):

\footnotetext{
9 Economic Policy Uncertainty website: http://policyuncertainty.com/global_monthly.html.
} 
Table 1 Descriptive statistics of the main variables

\begin{tabular}{|c|c|c|c|c|c|c|}
\hline Variable & Variable Name & Obs & Mean & Std. & Min. & Max. \\
\hline Num & Number of high-speed rail stations & 2640 & 1.464 & 2.187 & 0.000 & 11.000 \\
\hline Policy & Fiscal policy & 4576 & 0.312 & 0.464 & 0.000 & 1.000 \\
\hline Inf & Level of informatization & 4576 & -0.489 & 0.896 & -2.105 & 2.246 \\
\hline Gov & Level of government intervention & 4576 & 0.335 & 0.276 & 0.112 & 0.992 \\
\hline Open & Level of opening to the outside world & 4576 & 0.02 & 0.021 & 0.000 & 0.106 \\
\hline $\operatorname{Tr}$ & Transportation infrastructure & 4576 & 6.164 & 1.415 & 2.398 & 9.139 \\
\hline$P g d p$ & GDP per capita & 4576 & 4.712 & 0.034 & 4.620 & 4.811 \\
\hline$H c$ & Human capital & 4576 & 0.016 & 0.022 & 0.001 & 0.115 \\
\hline Ери & Uncertainty & 4576 & 0.438 & 0.496 & 0.000 & 1.000 \\
\hline Market & Degree of marketization & 4576 & 0.410 & 0.492 & 0.000 & 1.000 \\
\hline$T F P$ & Total factor productivity & 4576 & 1.636 & 0.749 & 0.150 & 2.914 \\
\hline $\operatorname{Inv}$ & Scale of investment & 4576 & 0.734 & 0.509 & 0.197 & 3.779 \\
\hline Hstru & Advanced industrial structure & 4576 & 0.871 & 0.415 & 0.223 & 2.687 \\
\hline Rstru & Rationalization of industrial structure & 4576 & 36.293 & 160.485 & 0.039 & 5284.329 \\
\hline GTFP & Urban economic efficiency & 4576 & -0.006 & 0.029 & -0.083 & 0.074 \\
\hline $\ln I w w$ & Industrial wastewater emissions & 4576 & 8.302 & 1.119 & 1.946 & 11.449 \\
\hline $\operatorname{lnISO}_{2}$ & Industrial sulfur dioxide emissions & 4576 & 10.353 & 1.198 & 0.693 & 13.434 \\
\hline $\operatorname{lnIsd}$ & Industrial smoke (Dust) emissions & 4576 & 9.694 & 1.161 & 2.398 & 15.458 \\
\hline
\end{tabular}

Compiled by the author

$$
\text { Num }_{\mathrm{it}}=\partial_{0}+\partial_{1} \text { Policy }_{\mathrm{it}}+\partial_{2} \text { Controls }_{\mathrm{it}}+u_{i}+\lambda_{t}+\varepsilon_{\mathrm{it}}
$$

where the dependent variable Num $_{i t}$ is the number of HSR stations, which measures the scale of investment in HSR construction in a city. The core explanatory variable Policy $_{\text {it }}$ is a dummy variable representing fiscal policy. It takes the value of 1 if city $\mathrm{i}$ is influenced by fiscal policy in year $\mathrm{t}$, and 0 otherwise. The regression coefficient focused on in the model is $\partial_{1}$. If the regression result of $\partial_{1}$ is significantly positive, it indicates that the implementation of fiscal policy promotes investment in urban high-speed rail construction. Controls is the set of all control variables in this paper. It includes the level of informatization (Inf), the degree of government intervention (Gov), the level of openness to the outside world (Open), transportation infrastructure $(T r)$, per capita GDP (Pgdp), and human capital $(H c) . u_{i}$ denotes regional fixed effects; $\lambda_{t}$ signifies time fixed effects; and $\varepsilon_{i t}$ is the error term. The definitions of all variables in the empirical study of this paper are shown in Table 1.

The last four columns of Table 1 report the descriptive statistical analysis of the main variables in this paper. The table shows that the mean value of the number of HSR stations is 1.464 , and the cities affected by fiscal policy account for $31.2 \%$ of the full sample. In addition, the mean value of the EPU index is 0.438 , and the mean value of marketization degree is 0.410 . The mean value of total factor productivity is 1.636; the mean value of investment scale is 0.734 ; the mean values of industrial structure rationalization index and industrial structure advanced index are 36.293 and 0.871 , respectively; and the mean values of industrial wastewater emission, 
Table 2 Benchmark results for fiscal policy and investments in high-speed rail construction

\begin{tabular}{|c|c|c|c|c|c|c|c|}
\hline Variables & (1) & (2) & (3) & (4) & (5) & (6) & (7) \\
\hline Policy & $\begin{array}{l}2.0581^{\text {**** }} \\
(36.84)\end{array}$ & $\begin{array}{l}2.0571^{\text {**:*k }} \\
(36.66)\end{array}$ & $\begin{array}{l}2.0127^{\text {****k }} \\
(34.95)\end{array}$ & $\begin{array}{l}1.9061^{* * * *} \\
(32.93)\end{array}$ & $\begin{array}{l}1.8948^{* * * * *} \\
(32.43)\end{array}$ & $\begin{array}{l}1.6380^{\text {***** }} \\
(23.35)\end{array}$ & $\begin{array}{l}1.5532^{\text {**** }} \\
(22.15)\end{array}$ \\
\hline $\operatorname{Inf}$ & & $\begin{array}{l}0.0140 \\
(0.17)\end{array}$ & $\begin{array}{l}0.0126 \\
(0.16)\end{array}$ & $\begin{array}{l}0.0850 \\
(1.08)\end{array}$ & $\begin{array}{l}0.0822 \\
(1.04)\end{array}$ & $\begin{array}{l}0.0713 \\
(0.91)\end{array}$ & $\begin{array}{l}0.0721 \\
(0.93)\end{array}$ \\
\hline Gov & & & $\begin{array}{l}-0.4502^{* * * *} \\
(-3.30)\end{array}$ & $\begin{array}{l}-0.4335^{\text {**** }} \\
(-3.23)\end{array}$ & $\begin{array}{l}-0.4244^{* * \cdot *} \\
(-3.16)\end{array}$ & $\begin{array}{l}-0.4841^{* * * *} \\
(-3.63)\end{array}$ & $\begin{array}{l}-0.3220^{\text {** }} \\
(-2.41)\end{array}$ \\
\hline Open & & & & $\begin{array}{l}-19.4846^{\text {****k }} \\
(-9.00)\end{array}$ & $\begin{array}{l}-19.3566^{* * *} \\
(-8.94)\end{array}$ & $\begin{array}{l}-18.3386^{* * *} \\
(-8.52)\end{array}$ & $\begin{array}{l}-15.0061^{* * *} \\
(-6.92)\end{array}$ \\
\hline$T r$ & & & & & $\begin{array}{l}0.0350 \\
(1.41)\end{array}$ & $\begin{array}{l}0.0330 \\
(1.34)\end{array}$ & $\begin{array}{l}0.0300 \\
(1.24)\end{array}$ \\
\hline$P g d p$ & & & & & & $\begin{array}{l}-7.9178^{* * * *} \\
(-6.49)\end{array}$ & $\begin{array}{l}-7.1885^{* * *} \\
(-5.95)\end{array}$ \\
\hline$H c$ & & & & & & & $\begin{array}{l}34.2908^{* * *} \\
(7.80)\end{array}$ \\
\hline Constant & $\begin{array}{l}0.6065^{* * * *} \\
(16.82)\end{array}$ & $\begin{array}{l}0.6114^{\text {**** }} \\
(13.34)\end{array}$ & $\begin{array}{l}0.7632^{\text {**** }} \\
(11.77)\end{array}$ & $\begin{array}{l}1.2533^{* * *} \\
(14.95)\end{array}$ & $\begin{array}{l}1.0271^{\text {皮决 }} \\
(5.69)\end{array}$ & $\begin{array}{l}38.3859^{* * *} \\
(6.67)\end{array}$ & $\begin{array}{l}34.2161^{\text {**** }} \\
(5.99)\end{array}$ \\
\hline$N$ & 2640 & 2640 & 2640 & 2640 & 2640 & 2640 & 2640 \\
\hline $\operatorname{adj} . R^{2}$ & 0.301 & 0.301 & 0.304 & 0.326 & 0.326 & 0.338 & 0.354 \\
\hline
\end{tabular}

$*, * *, * * *$ represent 10,5 , and $1 \%$ significance levels, respectively; $t$-values are reported in parentheses

industrial sulfur dioxide emission, and industrial smoke (Dust) emission are 8.302, 10.353, and 9.694, respectively. As for the control variables, the mean values of the degree of government intervention are 0.335 ; the mean value of human capital is 0.016; the mean values of the level of openness to the outside world and the level of informatization are 0.020 and -0.489 , respectively; and the mean values of transportation infrastructure and GDP per capita are 6.164 and 4.712, respectively.

\section{Empirical results and discussion}

\subsection{Baseline regression results}

Based on the difference-in-differences (DID) method, this paper presents an empirical analysis of the impact of the implementation of fiscal policy on investment in high-speed rail construction. The results of the baseline regression are shown in Table 2. In columns (1-7), the coefficients of the core explanatory variables Policy are all positive and pass the $1 \%$ significance test, which demonstrates that fiscal policy significantly contributes to investment in high-speed rail construction. In terms of economics, fiscal policy boosts investment in high-speed rail construction by 2.058 units. After adding control variables, the boosting effect of fiscal policy on investment in high-speed rail construction gradually decreases. In addition, following the regression results of the control variables, the degree of government intervention, the level of openness to the outside world, and the increase in GDP per capita significantly inhibit investments in HSR construction; the level of information technology and transportation infrastructure have a positive but insignificant effect 
on the investment in HSR construction, while the increase in human capital significantly promotes investment in HSR construction.

Overall, the empirical results in Table 2 show that fiscal policy encourages cities to enhance the investment scale of HSR construction, verifying Hypothesis 1. One possible reason is that the government's implementation of active fiscal policy tends to effectively reduce the degree of financing constraints of state-owned enterprises $\left(S O E_{s}\right)$, allowing them to obtain a large-scale supply of funds (Zhang 2015). This approach helps reduce the risk premium of external financing for enterprises, promotes infrastructure investment, and drives the formation of bank loans, social funds, and public capital (Li and Tian 2021; Xu et al. 2013; Zhang and Liu 2009). Moreover, most of the enterprises concentrating on high-speed railway construction projects are $S O E_{s}$. Therefore, implementing fiscal policies related to high-speed rail construction can help reduce the financing cost of regional projects and promote its investment.

\subsection{Robustness tests}

\subsubsection{PSM-DID method}

The treatment and control groups differ on the issue of sample selectivity. In order to exclude sample selection bias to address possible endogeneity problems caused by, for example, omitted variables, this paper combines the propensity score matching method (PSM) and the difference-in-differences method (DID) for robustness testing.

First, to exclude possible bias in the sample, the kernel density distributions of propensity scores of the treatment and control groups before and after matching are compared. The kernel density distributions of the propensity scores of the treatment and control groups before and after matching were observed, revealing that the kernel density distributions and smoothness of the curves did not change significantly, and the distributions before and after were similar. Thus, the sample bias in the quasi-natural experiment impacts the results only minimally. Second, individual characteristics such as the level of information technology (Inf), the degree of government intervention (Gov), the level of openness to the outside world (Open), transportation infrastructure $(T r)$, per capita GDP $(P g d p)$, and human capital $(H c)$ were selected as matching variables. The kernel matching method was used to match and remove the observations that did not satisfy the hypothesis.

Based on the above sample matching results, the DID method was used to verify the baseline regression results, which are shown in Table 3. Comparing the results, the coefficients of the core explanatory variable Policy are positive and pass the $1 \%$ significance test, regardless of whether control variables are added or not. This finding indicates that fiscal policy has a positive moderating effect on investment in high-speed rail construction. The results are generally consistent with the previous paper, indicating that the baseline regression results are robust. Therefore, after the matched regression of the sample using the PSM-DID method, it can be confirmed 
Table 3 PSM-DID test results

\begin{tabular}{llllllll}
\hline Variables & $(1)$ & $(2)$ & $(3)$ & $(4)$ & $(5)$ & $(6)$ & $(7)$ \\
\hline Policy & $1.6771^{* * *}$ & $1.6700^{* * *}$ & $1.6636^{* * *}$ & $1.6301^{* * *}$ & $1.6289^{* * *}$ & $1.4777^{* * *}$ & $1.3808^{* * *}$ \\
& $(20.85)$ & $(20.71)$ & $(20.53)$ & $(20.04)$ & $(19.99)$ & $(17.05)$ & $(15.53)$ \\
Inf & & 0.1348 & 0.1349 & 0.1679 & 0.1667 & $0.1843^{*}$ & 0.1780 \\
& & $(1.23)$ & $(1.23)$ & $(1.53)$ & $(1.52)$ & $(1.69)$ & $(1.65)$ \\
Gov & & & -0.2214 & -0.2784 & -0.2785 & $-0.5094^{*}$ & $-0.4737^{*}$ \\
& & & $(-0.83)$ & $(-1.04)$ & $(-1.04)$ & $(-1.89)$ & $(-1.77)$ \\
Open & & & & $-12.4347^{* * *}$ & $-12.4194^{* * *}$ & $-12.6893^{* * *}$ & $-10.8903^{* * *}$ \\
& & & & $(-3.28)$ & $(-3.27)$ & $(-3.37)$ & $(-2.89)$ \\
Tr & & & & & 0.0096 & 0.0087 & 0.0077 \\
& & & & & $(0.29)$ & $(0.26)$ & $(0.23)$ \\
Pgdp & & & & & & $-11.3575^{* * *}$ & $-11.2838^{* * *}$ \\
& & & & & & $(-4.81)$ & $(-4.81)$ \\
Hc & & & & & & & $29.0251^{* * *}$ \\
& & & & & & & $(4.35)$ \\
Constant & $0.9556^{* * *}$ & $0.9995^{* * *}$ & $1.0583^{* * *}$ & $1.3443^{* * *}$ & $1.2811^{* * *}$ & $54.7062^{* * *}$ & $53.7633^{* * *}$ \\
& $(14.14)$ & $(13.08)$ & $(10.13)$ & $(9.90)$ & $(4.95)$ & $(4.93)$ & $(4.87)$ \\
$N$ & 1513 & 1513 & 1513 & 1513 & 1513 & 1513 & 1513 \\
adj. $R^{2}$ & 0.124 & 0.125 & 0.124 & 0.131 & 0.130 & 0.145 & 0.157 \\
\hline
\end{tabular}

$*, * *, * * *$ represent 10,5 , and $1 \%$ significance levels, respectively; $t$-values are reported in parentheses

that the implementation of fiscal policy does help to increase the investment scale of high-speed railway construction.

\subsubsection{Poisson's pseudo-maximum likelihood (PPML) method}

In the course of the empirical study, we could not completely exclude the influence of factors other than fiscal policy. Therefore, the omitted variables may be correlated with the explanatory variables, creating an endogeneity problem and leading to biased regression results. Therefore, this paper uses Poisson's pseudo-maximum likelihood estimation method (PPML) for robustness testing to address possible endogeneity issues, further validate the impact of fiscal policy on investment in HSR construction, and enhance the credibility of the findings. The regression results are shown in Table 4. Observing Table 4, the coefficient estimates of the key explanatory variable Policy are positive and pass the $1 \%$ significance test, regardless of whether control variables are included or not. It indicates that the implementation of fiscal policy has a positive contribution to high-speed rail construction investment, which is consistent with the results of the previous benchmark regression. Therefore, the conclusions drawn in the benchmark regression model are plausible.

\subsubsection{Instrumental variable test}

The empirical results in the previous section may suffer from endogeneity problems, considering that potentially unobservable factors can affect investment in HSR construction. Therefore, in this paper, a one-period lag of fiscal policy is used as the 
Table 4 PPLM test results

\begin{tabular}{|c|c|c|c|c|c|c|c|}
\hline Variables & (1) & (2) & (3) & (4) & (5) & (6) & (7) \\
\hline Policy & $\begin{array}{l}1.4801^{* * *} \\
(23.11)\end{array}$ & $\begin{array}{l}1.4618^{\text {**** }} \\
(24.63)\end{array}$ & $\begin{array}{l}1.4640^{* * *} \\
(24.34)\end{array}$ & $\begin{array}{l}1.4833^{\text {**** }} \\
(24.12)\end{array}$ & $\begin{array}{l}1.4529^{* * *} \\
(23.67)\end{array}$ & $\begin{array}{l}1.2514^{\text {**** }} \\
(18.61)\end{array}$ & $\begin{array}{l}1.2412^{\text {*** }} \\
(18.50)\end{array}$ \\
\hline $\operatorname{Inf}$ & & $\begin{array}{l}0.5291^{* * *} \\
(21.51)\end{array}$ & $\begin{array}{l}0.5286^{\text {**** }} \\
(21.44)\end{array}$ & $\begin{array}{l}0.5106^{* * * *} \\
(19.34)\end{array}$ & $\begin{array}{l}0.4565^{* * *} \\
(16.35)\end{array}$ & $\begin{array}{l}0.4104^{\text {**** }} \\
(14.85)\end{array}$ & $\begin{array}{l}0.3687^{\text {**** }} \\
(12.17)\end{array}$ \\
\hline Gov & & & $\begin{array}{l}0.0179 \\
(0.17)\end{array}$ & $\begin{array}{l}0.0281 \\
(0.27)\end{array}$ & $\begin{array}{l}0.0093 \\
(0.09)\end{array}$ & $\begin{array}{l}0.0095 \\
(0.09)\end{array}$ & $\begin{array}{l}0.0383 \\
(0.36)\end{array}$ \\
\hline Open & & & & $\begin{array}{l}2.4142^{* *} \\
(2.15)\end{array}$ & $\begin{array}{l}1.8749 * \\
(1.67)\end{array}$ & $\begin{array}{l}2.6490 * * \\
(2.39)\end{array}$ & $\begin{array}{l}2.1570^{*} \\
(1.92)\end{array}$ \\
\hline $\operatorname{Tr}$ & & & & & $\begin{array}{l}0.0944^{* * *} \\
(4.99)\end{array}$ & $\begin{array}{l}0.0969^{* * *} \\
(5.10)\end{array}$ & $\begin{array}{l}0.0905^{\text {*** }} \\
(4.79)\end{array}$ \\
\hline$P g d p$ & & & & & & $\begin{array}{l}-7.4018^{\text {*** }} \\
(-7.35)\end{array}$ & $\begin{array}{l}-7.2198^{\text {*** }} \\
(-7.17)\end{array}$ \\
\hline$H c$ & & & & & & & $\begin{array}{l}3.0672^{* * *} \\
(3.40)\end{array}$ \\
\hline Constant & $\begin{array}{l}-0.5001^{\text {**** }} \\
(-8.73)\end{array}$ & $\begin{array}{l}-0.4388^{* * * *} \\
(-8.32)\end{array}$ & $\begin{array}{l}-0.4453^{\text {*** }} \\
(-6.97)\end{array}$ & $\begin{array}{l}-0.5169^{* * *} \\
(-7.02)\end{array}$ & $\begin{array}{l}-1.1200^{* * *} \\
(-8.05)\end{array}$ & $\begin{array}{l}33.7150^{* * *} \\
(7.11)\end{array}$ & $\begin{array}{l}32.8326^{* * * *} \\
(6.92)\end{array}$ \\
\hline$N$ & 2640 & 2640 & 2640 & 2640 & 2640 & 2640 & 2640 \\
\hline $\operatorname{adj} \cdot R^{2}$ & 0.215 & 0.349 & 0.349 & 0.351 & 0.360 & 0.357 & 0.360 \\
\hline
\end{tabular}

$*, * *, * * *$ represent 10,5 , and $1 \%$ significance levels, respectively; $t$-values are reported in parentheses

Table 5 Test results of the instrumental variables

\begin{tabular}{lll}
\hline Variables & $\begin{array}{l}\text { Stage 1 } \\
\text { Policy }\end{array}$ & $\begin{array}{l}\text { Stage 2 } \\
\text { Num }\end{array}$ \\
\hline $\begin{array}{l}\text { L_Policy } \\
\text { Policy }\end{array}$ & $0.5372^{* * *}(33.23)$ & \\
& & $1.9695^{* * *}$ \\
Controls & Yes & $(14.04)$ \\
Constant & $23.2009^{* * *}$ & Yes \\
N & $(17.98)$ & $20.5360^{* * *}$ \\
adj. $R^{2}$ & 2639 & $(2.64)$ \\
\hline
\end{tabular}

$*, * *, * * *$ represent 10,5 , and $1 \%$ significance levels, respectively; $t$-values are reported in parentheses

instrumental variable, and the two-stage least squares (2SLS) method is used to test the instrumental variable. Theoretically, the reasonableness of choosing fiscal policy lagged by one period as an instrumental variable is that: (i) in terms of correlation, fiscal policy lagged by one period has a high correlation with current fiscal policy; (ii) in terms of exclusivity, fiscal policy with a one-period lag will not impact HSR construction investment through current fiscal policy.

Table 5 reports the estimation results of the instrumental variables. In particular, column (1) shows the regression results for the lagged one period of fiscal policy as an instrumental variable, and column (2) shows the regression results for the second 
Table 6 High-speed rail construction investment agent indicators

\begin{tabular}{llllllll}
\hline Variables & $(1)$ & $(2)$ & $(3)$ & $(4)$ & $(5)$ & $(6)$ & $(7)$ \\
& Hsrf & Hsrf & Hsrf & Hsrf & Hsrf & Hsrf & Hsrf \\
\hline Policy & $1.3607^{* * *}$ & $1.3538^{* * *}$ & $1.2807^{* * *}$ & $1.2717^{* * *}$ & $1.2662^{* * *}$ & $0.8829^{* * *}$ & $0.8158^{* * *}$ \\
& $(26.16)$ & $(26.31)$ & $(24.72)$ & $(24.40)$ & $(24.30)$ & $(15.47)$ & $(14.43)$ \\
Inf & & $0.3718^{* * *}$ & $0.3415^{* * *}$ & $0.3497^{* * *}$ & $0.3439^{* * *}$ & $0.2347^{* * *}$ & $0.2459^{* * *}$ \\
& & $(4.69)$ & $(4.38)$ & $(4.48)$ & $(4.41)$ & $(3.23)$ & $(3.47)$ \\
Gov & & & $-0.7513^{* * *}$ & $-0.7570^{* * *}$ & $-0.7575^{* * *}$ & $-0.6715^{* * *}$ & $-0.5844^{* * *}$ \\
& & & $(-6.17)$ & $(-6.22)$ & $(-6.24)$ & $(-5.97)$ & $(-5.29)$ \\
Open & & & & -3.5446 & -3.4084 & $-3.7230^{*}$ & -2.9397 \\
& & & & $(-1.51)$ & $(-1.45)$ & $(-1.71)$ & $(-1.38)$ \\
Tr & & & & & $0.0422^{* *}$ & 0.0294 & $0.0327^{*}$ \\
& & & & & $(2.00)$ & $(1.51)$ & $(1.72)$ \\
Pgdp & & & & & & $-14.5549^{* * *}$ & $-12.9898^{* * *}$ \\
& & & & & & $(-12.51)$ & $(-11.22)$ \\
Hc & & & & & & & $43.9704^{* * *}$ \\
& & & & & & & $(6.91)$ \\
Constant & $3.2651^{* * *}$ & $3.3028^{* * *}$ & $3.5599^{* * *}$ & $3.6512^{* * *}$ & $3.3676^{* * *}$ & $72.0173^{* * * *}$ & $63.4975^{* * *}$ \\
& $(99.88)$ & $(99.15)$ & $(67.26)$ & $(45.37)$ & $(20.70)$ & $(13.12)$ & $(11.56)$ \\
$N$ & 1105 & 1105 & 1105 & 1105 & 1105 & 1105 & 1105 \\
adj. $R^{2}$ & 0.311 & 0.326 & 0.352 & 0.353 & 0.355 & 0.449 & 0.476 \\
\hline
\end{tabular}

$*, * *, * * *$ represent 10,5 , and $1 \%$ significance levels, respectively; $t$-values are reported in parentheses

stage of the instrumental variables method. The coefficient estimate of $L \_$Policy in (1) is positive and passes the $1 \%$ significance test, indicating a significant positive relationship between the one-period lag of fiscal policy and current fiscal policy. In column (2), the policy coefficient, the key explanatory variable in this paper, is still significantly positive at the $1 \%$ level. These results indicate that fiscal policy implementation still helps increase the scale of investment in HSR construction after further addressing the endogeneity of treatment group selection. The findings indirectly reflect the correctness of the chosen estimation method and the robustness of the underlying findings.

\subsubsection{Replacing the investment agent indicators for high-speed rail construction}

Considering that the differences in the proxies of HSR construction investment may affect the basic conclusions of this paper, we further draw on the study of Li et al. (2021) and use the number of HSR stops in cities ${ }^{10}$ as a proxy variable for HSR construction investment to conduct robustness tests. The regression results are shown in Table 6. The coefficients of the core explanatory variables are all significantly positive at the $1 \%$ level, consistent with the baseline regression results, further verifying that fiscal policy has a significant promotion effect on the investment in high-speed

\footnotetext{
${ }^{10}$ Data on the number of high-speed rail stops in each city are drawn from the National Railway Passenger Train Timetable 2007-2016.
} 
rail construction. In addition, the regression results of the control variables remain consistent with the benchmark regression results. The above results indicate that the primary conclusion of this paper still holds after replacing the proxy variables for HSR construction investment, i.e., the conclusion that fiscal policy helps promote HSR construction investment is reliable.

\subsection{Heterogeneity analysis}

\subsubsection{Impact of economic policy uncertainty}

Economic policy uncertainty factors may skew the effect of fiscal policy on highspeed rail construction investment. Consequently, the sample cities are divided into those with high and low economic policy uncertainty. The regression results are shown in Table 7. Columns (1) and (2) display the regression results for high economic policy uncertainty, and columns (3) and (4) list the regression results for low economic policy uncertainty. The odd columns are the results without including control variables, and the even columns are the results with control variables.

The results show that the coefficients of the core explanatory variable Policy are all significantly positive at the $1 \%$ level, indicating that fiscal policy positively affects investment in HSR construction in cities with high and low economic policy uncertainty. However, the positive impact of fiscal policy on HSR construction investment is more significant in cities with high economic policy uncertainty relative to cities with low economic policy uncertainty. The possible reason for this finding is the coupling effect between economic policy uncertainty and regional innovation. In an environment with a high degree of economic policy uncertainty, regions will invest in innovation to resolve market risks (Yuan and Li 2021). Faced with the government's active fiscal policy to encourage the development of green infrastructure, cities with a higher degree of economic policy uncertainty have more incentives to increase the scale of investment in HSR construction to drive the region's economic development.

Table 7 Differences in the degree of economic policy uncertainty

\begin{tabular}{llllll}
\hline Variables & \multicolumn{2}{l}{$\begin{array}{l}\text { High economic policy } \\
\text { uncertainty }\end{array}$} & \multicolumn{2}{l}{$\begin{array}{l}\text { Low economic policy } \\
\text { uncertainty }\end{array}$} \\
\cline { 2 - 3 } \cline { 5 - 6 } & $(1)$ & $(2)$ & & $(3)$ & $(4)$ \\
\hline Policy & $2.2042^{* * *}$ & $1.7559^{* * *}$ & $1.3125^{* * *}$ & $0.9060^{* * *}$ \\
& $(29.86)$ & $(16.60)$ & $(14.53)$ & $(9.53)$ \\
Controls & No & Yes & No & Yes \\
Constant & $0.6561^{* * *}$ & $34.2140^{* * *}$ & $0.5693^{* * *}$ & $27.1012^{* * *}$ \\
N & $(11.76)$ & $(3.70)$ & $(14.10)$ & $(4.08)$ \\
adj. $R^{2}$ & 1540 & 1540 & 1100 & 1100 \\
\hline
\end{tabular}

$*, * *, * * *$ represent 10,5 , and $1 \%$ significance levels, respectively; $t$-values are reported in parentheses 


\subsubsection{Impact of marketization degree}

Economic and social development levels vary widely among regions in China, and the degree of marketization also noticeably fluctuates. The impact of fiscal policy on infrastructure construction may differ among cities with distinct degrees of marketization. To further test the impact of fiscal policy on investment in HSR construction in cities with different marketization degrees, this paper divides the sample cities into those with high and low degrees of marketization based on the median marketization degree of cities.

Table 8 reports the regression results of fiscal policy and investment in HSR construction conditional on the difference in the degree of marketization. Columns (1) and (2) show the regression results for high marketization, and columns (3) and (4) outline the regression results for low marketization. The odd columns display the results without including control variables, and the even columns add the control variables. The regression coefficients of the core explanatory variable Policy are all positive and pass the $1 \%$ significance level test. This result indicates that fiscal policy helps to increase the scale of investment in HSR construction in both high and low market-oriented cities. In addition, the regression results for different degrees of marketization indicate that the positive impact of fiscal policy on investment in HSR construction in cities with high marketization is greater relative to cities with low marketization. It is possible that the increase in marketization degree has a significant promotion effect on cities' optimal resource allocation, technological progress, and innovation (Zhang et al. 2017a, b, c). Further, as a vital type of green transportation infrastructure, high-speed rail has more potential to develop in cities with high marketization degrees with the encouragement of government fiscal policies.

\subsubsection{City characteristics}

4.3.3.1 Heterogeneity of urban development levels Considering the possible heterogeneous effects of fiscal policy on HSR construction investment in cities with different development levels, this paper divides the total sample into first-tier cities,

Table 8 Differences in the degree of marketization

\begin{tabular}{llllll}
\hline Variables & \multicolumn{2}{l}{ High marketization } & & \multicolumn{2}{l}{ Low marketization } \\
\cline { 2 - 3 } \cline { 5 - 6 } \cline { 5 - 6 } & $(1)$ & $(2)$ & & $(3)$ & $(4)$ \\
\hline Policy & $2.3557^{* * * *}$ & $1.6988^{* * *}$ & & $1.6620^{* * *}$ & $1.2774^{* * *}$ \\
& $(24.05)$ & $(13.64)$ & & $(25.45)$ & $(16.20)$ \\
Controls & No & Yes & & No & Yes \\
Constant & $0.7807^{* * *}$ & $49.7725^{* * *}$ & & $0.4389^{* * *}$ & $26.2302^{* * *}$ \\
& $(12.24)$ & $(4.48)$ & & $(11.64)$ & $(4.57)$ \\
$N$ & 1321 & 1321 & & 1319 & 1319 \\
adj. $R^{2}$ & 0.229 & 0.290 & & 0.262 & 0.309 \\
\hline
\end{tabular}

$*, * *, * * *$ represent 10,5 , and $1 \%$ significance levels, respectively; $t$-values are reported in parentheses 
Table 9 Heterogeneity of urban development levels

\begin{tabular}{llllll}
\hline Variables & $\begin{array}{l}\text { First-tier cities } \\
(1)\end{array}$ & $\begin{array}{l}\text { Second-tier cities } \\
(2)\end{array}$ & $\begin{array}{l}\text { Third-tier cities } \\
(3)\end{array}$ & $\begin{array}{l}\text { Fourth-tier cities } \\
(4)\end{array}$ & $\begin{array}{l}\text { Fifth-tier cities } \\
(5)\end{array}$ \\
\hline Policy & $3.2279^{* * *}$ & $1.5854^{* * *}$ & $1.3792^{* * *}$ & $1.4384^{* * *}$ & $1.0051^{* * *}$ \\
& $(8.14)$ & $(7.73)$ & $(11.53)$ & $(14.25)$ & $(9.90)$ \\
Controls & Yes & Yes & Yes & Yes & Yes \\
Constant & $186.3976^{* * *}$ & $101.3639^{* * *}$ & $46.5347^{* * *}$ & $19.6566^{* *}$ & $22.0450^{* * *}$ \\
& $(4.63)$ & $(4.48)$ & $(4.40)$ & $(2.44)$ & $(3.44)$ \\
$N$ & 228 & 360 & 780 & 756 & 516 \\
adj. $R^{2}$ & 0.512 & 0.415 & 0.361 & 0.412 & 0.357 \\
\hline
\end{tabular}

$*$, **, ***represent 10,5 , and $1 \%$ significance levels, respectively; $t$-values are reported in parentheses

second-tier cities, third-tier cities, fourth-tier cities, and fifth-tier cities in terms of city development levels. The estimation results for each sample city are shown in Table 9. The results indicate that the coefficient estimates of the core explanatory variable Policy are all positive and pass the significance level test of at least $1 \%$, indicating that fiscal policy positively contributes to investment in HSR construction in cities of different levels.

Meanwhile, a cross-sectional comparison of the coefficient estimates of the core explanatory variable Policy reveals that fiscal policy has the greatest impact on HSR construction investment in Tier 1 cities, the second-highest impact on HSR construction investment in Tier 2 cities, a lesser impact on HSR construction investment in Tier 3 and Tier 4 cities, and the most minimal impact on HSR construction investment in Tier 5 cities. The above empirical results show that the effect of fiscal policy on the enhancement of HSR construction investment is more significant in Tier 1 and Tier 2 cities based on the urban development hierarchy perspective. Tier 1 and Tier 2 cities have relatively better public services and infrastructure, which can lead to the agglomeration of enterprises and population and reduce factor transportation costs. In order to maintain the competitiveness of urban development, the government will increase the investment scale of high-speed railway construction with the support of fiscal policy and increase the investment in infrastructure to promote high-quality urban economic development.

4.3.3.2 City administrative hierarchy heterogeneity Considering that the administrative level of cities may lead to a differential impact of fiscal policy on investment in high-speed rail construction, this paper divides the total sample into provincial capital and non-capital cities. It continues to use the fixed-effects model for regression to examine the heterogeneous impact of fiscal policy on the investment in urban high-speed rail construction at different administrative levels. The estimation results for each sample city are shown in Table 10. Columns (1) and (2) list the regression results for provincial capital cities, and columns (3) and (4) display the regression results for non-capital cities. No control variables are included in the odd columns but are added to the even columns. The results show that the coefficient estimates of the core explanatory variable Policy are positive and pass 
Table 10 City administrative hierarchy heterogeneity

\begin{tabular}{llllll}
\hline Variables & \multicolumn{2}{l}{ Provincial capital cities } & & \multicolumn{2}{l}{ Non-provincial cities } \\
\cline { 2 - 3 } \cline { 5 - 6 } \cline { 5 - 6 } & $(1)$ & $(2)$ & & $(3)$ & $(4)$ \\
\hline Policy & $3.2933^{* * *}$ & $2.3292^{* * *}$ & & $1.8630^{* * *}$ & $1.4283^{* * *}$ \\
& $(14.77)$ & $(8.13)$ & & $(35.12)$ & $(21.63)$ \\
Controls & Yes & Yes & & Yes & Yes \\
Constant & $1.3000^{* * *}$ & $119.5049^{* * *}$ & & $0.4970^{* * *}$ & $25.2799^{* * *}$ \\
& $(9.03)$ & $(4.51)$ & & $(14.51)$ & $(4.77)$ \\
$N$ & 360 & 360 & & 2280 & 2280 \\
adj. $R^{2}$ & 0.344 & 0.390 & & 0.314 & 0.378 \\
\hline
\end{tabular}

*, **, *** represent $10 \%, 5 \%$, and $1 \%$ significance levels, respectively; $\mathrm{t}$-values are reported in parentheses

Table 11 City scale heterogeneity

\begin{tabular}{llllll}
\hline Variables & $\begin{array}{l}\text { Mega-cities } \\
(1)\end{array}$ & $\begin{array}{l}\text { Super cities } \\
(2)\end{array}$ & $\begin{array}{l}\text { Large cities } \\
(3)\end{array}$ & $\begin{array}{l}\text { Mid-sized cities } \\
(4)\end{array}$ & $\begin{array}{l}\text { Small cities } \\
(5)\end{array}$ \\
\hline Policy & $2.3131^{* * *}$ & $2.5988^{* * *}$ & $\begin{array}{l}1.3999^{* * *} \\
(15.52)\end{array}$ & $\begin{array}{l}1.4267^{* * *} \\
(14.12)\end{array}$ & $\begin{array}{l}1.5413^{* * *} \\
(6.39)\end{array}$ \\
Controls & $(4.07)$ & $(5.20)$ & Yes & Yes & Yes \\
Constant & $249.1163^{* * *}$ & $94.4674^{*}$ & $54.0443^{* * *}$ & 9.0454 & 19.3407 \\
& $(3.49)$ & $(1.86)$ & $(6.80)$ & $(1.27)$ & $(1.14)$ \\
$N$ & 96 & 144 & 1416 & 792 & 192 \\
adj. $R^{2}$ & 0.527 & 0.397 & 0.369 & 0.389 & 0.336 \\
\hline
\end{tabular}

$*, * *, * * *$ represent 10,5 , and $1 \%$ significance levels, respectively; $t$-values are reported in parentheses

the $1 \%$ significance level test, indicating that fiscal policy has a positive effect on investment in HSR construction in both provincial and non-provincial capitals.

However, the positive effect of fiscal policy on investment in HSR construction in provincial capitals is greater than that in non-capital cities. It is possible that provincial capitals, as cities of high administrative rank, have higher policy support and breadth than cities of low administrative rank. Therefore, they can attract more fiscal and human capital in their economic development process, have more authority to make policies and allocate resources, and can quickly deploy resources to promote the construction of low-carbon cities (Wang and She 2020). As an essential part of green infrastructure construction, the government will continue to increase investment in high-speed railway construction in provincial capital cities.

4.3.3.3 City scale heterogeneity From the perspective of city size, this paper classifies the sample cities into five categories: mega-cities (more than 10 million people), super cities (5-10 million people), large cities (1-5 million people), medium cities (500,000-1 million people), and small cities (less than 500,000 people), and further tests the effect of fiscal policy on the investment in HSR construction in cit- 
ies of different sizes heterogeneous effects. The estimation results for each sample city are shown in Table 11 . The results show that the coefficient estimates of the core explanatory variable Policy are all positive and pass the significance level test of at least $1 \%$, indicating that fiscal policy has a significant positive contribution to the investment in HSR construction in cities of different sizes.

A cross-sectional comparison of the coefficient estimates of the core explanatory variable Policy reveals that the positive effect of fiscal policy on investment in HSR construction is greatest in mega-cities and super cities, second in medium-sized and small cities, and lowest in large cities. The above empirical results suggest that the enhancement effect of fiscal policy on HSR construction investment is more significant in mega-cities and super cities based on the perspective of city size. The possible reason for this is that larger cities easily attract more investment and enhance the allocation efficiency and use efficiency of urban factor resources through their agglomeration economies, promoting urban economic growth (Hu et al. 2020). However, in order to meet the demand for higher quality and more infrastructure services in cities, the government must adopt an active fiscal policy to increase the scale of investment in HSR construction.

4.3.3.4 City cluster heterogeneity To test whether the characteristics of Chinese urban agglomerations differentially impact fiscal policy in relation to HSR construction investment, this paper considers eight major urban agglomerations in China: Beibu Gulf, Chengdu-Chongqing, Ha-Chang, Beijing-Tianjin-Hebei, the Yangtze River midstream urban agglomeration, the Yangtze River Delta, the Central Plains, and the Pearl River Delta. The city samples are classified to examine further the heterogeneous effects of fiscal policies on investment in HSR construction in different city clusters. The estimation results for each sample city are shown in Table 12. The results show that the coefficient estimates of the core explanatory variable Policy are all positive and pass the significance level test of at least $1 \%$, indicating that fiscal policy positively contributes to investment in HSR construction in different urban clusters.

A cross-sectional comparison of the coefficient estimates of the core explanatory variable policy reveals that the positive effect of fiscal policy on investment in HSR construction is more significant in the middle reaches of the Yangtze River urban agglomeration, the Yangtze River Delta urban agglomeration, the Central Plains urban agglomeration, and the Pearl River Delta urban agglomeration. The positive effect of fiscal policy on investment in HSR construction is second in the Beibu Gulf urban agglomeration, Chengdu-Chongqing urban agglomeration, and Ha-Chang urban agglomeration. In the Beijing-Tianjin-Hebei urban agglomeration, the fiscal policy has the most negligible effect on the investment in high-speed railway construction. In summary, the estimation results in Table 12 indicate that the enhancement effect of fiscal policy on high-speed rail construction investment is better in the middle reaches of the Yangtze River urban agglomeration, the Yangtze River Delta urban agglomeration, the Central Plains urban agglomeration, and the Pearl River Delta urban agglomeration. These four city clusters have higher openness and a stronger fiscal base (Cheng 2021), and the government faces a lower degree of financing constraints when adopting active fiscal policies. In order to improve the 


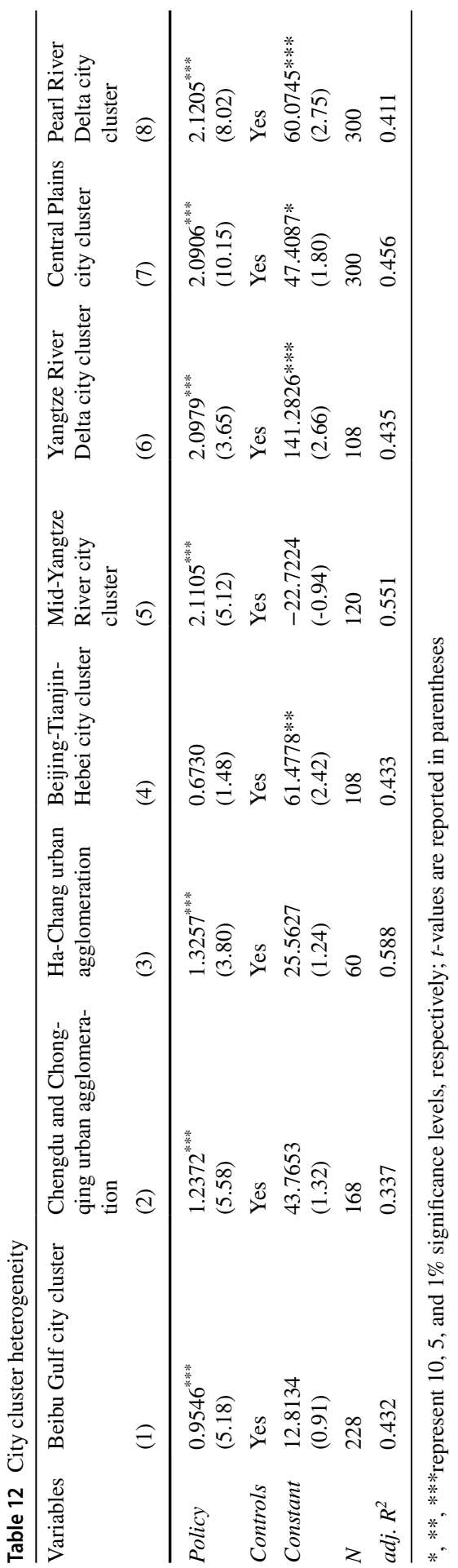


Table 13 East-middle-west heterogeneity

\begin{tabular}{|c|c|c|c|c|c|c|}
\hline \multirow[t]{2}{*}{ Variables } & \multicolumn{2}{|c|}{ Eastern region } & \multicolumn{2}{|c|}{ Central region } & \multicolumn{2}{|c|}{ Western region } \\
\hline & (1) & (2) & (3) & (4) & (5) & (6) \\
\hline Policy & $\begin{array}{l}2.0370^{\text {**** }} \\
(22.21)\end{array}$ & $\begin{array}{l}1.3314^{* * * *} \\
(11.72)\end{array}$ & $\begin{array}{l}2.0586^{\text {*** }} \\
(22.17)\end{array}$ & $\begin{array}{l}1.6448^{* * * *} \\
(13.78)\end{array}$ & $\begin{array}{l}2.0954^{\text {*** }} \\
(19.94)\end{array}$ & $\begin{array}{l}1.7698^{* * * *} \\
(12.06)\end{array}$ \\
\hline Controls & No & Yes & No & Yes & No & Yes \\
\hline Constant & $\begin{array}{l}1.0157^{\text {*** }} \\
(17.15)\end{array}$ & $\begin{array}{l}45.1601^{* * *} \\
(3.94)\end{array}$ & $\begin{array}{l}0.4503^{* * *} \\
(7.51)\end{array}$ & $\begin{array}{l}33.3792^{* * * *} \\
(3.60)\end{array}$ & $\begin{array}{l}0.1086 \\
(1.60)\end{array}$ & $\begin{array}{l}20.2321^{* *} \\
(2.14)\end{array}$ \\
\hline$N$ & 1092 & 1092 & 948 & 948 & 600 & 600 \\
\hline $\operatorname{adj} . R^{2}$ & 0.269 & 0.362 & 0.303 & 0.342 & 0.367 & 0.375 \\
\hline
\end{tabular}

$*, * *, * * *$ represent 10,5 , and $1 \%$ significance levels, respectively; $t$-values are reported in parentheses

rapid railroad transportation system of urban clusters, the government will increase the scale of investment in high-speed railway construction to promote the sustainable development of urban clusters.

\subsubsection{Location}

Although fiscal policy significantly contributes to increasing the scale of investment in local HSR construction, geographic location is a critical factor affecting economic development and construction investment in different regions of China. This feature leads to significant differences in the level of economic development, infrastructure conditions, human capital status, and marketization level throughout China (Lu et al. 2019; Pan and Zheng 2020; Zhang et al. 2017a, b, c), and their investment needs for economic development and infrastructure construction. So do geographic location factors lead to differential effects of fiscal policy on investment in HSR construction? In order to explore the possible differential impact of geographic location on fiscal policy concerning the enhancement of investment in high-speed railway construction, this paper divides all cities into eastern, central, and western cities and port and non-port cities according to their geographic locations and performs a subsample regression of Eq. (1), respectively.

Table 13 reports the regression results of fiscal policy and investment in HSR construction under the subsample of cities in the east, central, and west regions. As shown in Table 13, columns (1-2) show the regression results for the eastern region, columns (3-4) depict the regression results for the central region, and columns (5-6) list the regression results for the western region. Control variables are not included in the odd columns but are added to the even columns. First, the regression coefficients of the core explanatory variable Policy are all significantly positive at the $1 \%$ level, indicating that fiscal policy helps to increase the scale of investment in HSR construction in both the east and central regions. Second, the economic aspect shows that before including the control variables, fiscal policy raises the investment scale of high-speed railway construction by 2.037, 2.059, and 2.095 units in the eastern, central, and western regions, respectively. After including the control variables, fiscal policy raises the high-speed railway construction investment scale by 1.331 , 
Table 14 Port and non-port area heterogeneity

\begin{tabular}{llllll}
\hline Variables & \multicolumn{2}{l}{ Port areas } & & \multicolumn{2}{l}{ Non-port areas } \\
\cline { 2 - 3 } \cline { 5 - 6 } & $(1)$ & $(2)$ & & $(3)$ & $(4)$ \\
\hline Policy & $2.4461^{* * *}$ & $1.7568^{* * *}$ & & $1.6972^{* * *}$ & $1.3238^{* * *}$ \\
& $(26.37)$ & $(15.01)$ & & $(26.94)$ & $(16.43)$ \\
Controls & No & Yes & & No & Yes \\
Constant & $0.9501^{* * *}$ & $52.6009^{* * *}$ & & $0.2870^{* * * *}$ & $22.7143^{* * *}$ \\
& $(15.87)$ & $(5.20)$ & & $(7.06)$ & $(3.68)$ \\
$N$ & 1272 & 1272 & & 1368 & 1368 \\
adj. $R^{2}$ & 0.317 & 0.376 & & 0.309 & 0.347
\end{tabular}

$*, * *, * * *$ represent 10,5 , and $1 \%$ significance levels, respectively; $t$-values are reported in parentheses

1.645, and 1.770 units in the eastern, central, and western regions, respectively. Third, the regression results of the control variables show that GDP per capita has a significant adverse effect on the investment in high-speed railway construction in the eastern, central, and western regions. In contrast, human capital has a significant positive effect on the investment in high-speed railway construction in the eastern, central, and western regions.

In addition, comparing the regression results for the eastern, central, and western regions reveals that fiscal policy has a greater positive impact on HSR construction investment in cities in the central and western regions and a lesser effect in the eastern region. This difference may result from the current approach to high-speed railway construction in China, which has started to gradually radiate from the eastern coastal region to the central and western regions (Liu and Bai 2020). At the same time, in the face of the requirements of the era of high-quality transportation development and government fiscal policies supporting high-speed railway construction, high-speed railway, as a new type of transportation facility to promote the coordinated development of the east and west regions, has more room for construction and obvious latecomer advantages in the central and western regions.

Table 14 reports the regression results of fiscal policy and investment in HSR construction under the subsample of cities in port and non-port areas. First, columns (1)-(2) show the regression results for port areas. Before adding the control variables, the regression coefficient of the core explanatory variable Policy is significantly positive at the $1 \%$ level, and fiscal policy raises the investment in HSR construction in port cities by 2.446 units; after adding the control variables, the regression coefficient of Policy is still significantly positive, and fiscal policy raises the investment in HSR construction in port cities by 1.757 units. Second, columns (3-4) show the regression results for non-port areas. Similar to the regression results for port cities, the regression coefficients of the core explanatory variable Policy are positive and pass the $1 \%$ significance level test. Before including the control variables, fiscal policy boosted the investment in HSR construction in non-port cities by 1.697 units; after the inclusion of the control variables, fiscal policy boosted the investment in HSR construction in non-port cities by 1.324 units. Third, the regression results of the control variables show that the effect of GDP per capita on the investment in 
high-speed rail construction in both port and non-port areas is significantly negative, and the effect of human capital on the investment in high-speed rail construction in both areas is significantly positive. Finally, combining the above empirical results, fiscal policy helps to increase the scale of investment in HSR construction in both port and non-port area cities.

However, the positive effect of fiscal policy on investment in HSR construction is greater in port area cities than in non-port area cities. This phenomenon may be because port areas are fundamentally cities with developed coastal economies, apparent location advantages, and high population mobility. With rapid economic growth, the investment intensity and investment demand for transportation infrastructure construction are higher. In contrast, the development demand for transportation infrastructure in non-port areas lags behind that in port areas, and thus, the process of upgrading investment in high-speed rail construction is relatively slow.

\section{Further research: firm benefits of investment in HSR construction}

\subsection{High-speed rail construction investment and economic benefits}

Based on the ordinary least squares (OLS) equation, this paper draws on Cai and Chen (2020) to measure the long-term economic performance of HSR construction investment using changes in urban productivity (TFP) and investment size (Inv). Specifically, the difference in TFP one year before and after the occurrence of HSR construction investment $(\triangle T F P 1)$, the difference between the mean value of TFP two years after the occurrence of HSR construction investment and the previous year $(\triangle T F P 2)$, and the difference between the mean value of TFP three years after the occurrence of HSR construction investment and the previous year $(\triangle T F P 3)$ are calculated. The same method is used to calculate $\Delta \operatorname{Inv} 1, \Delta \operatorname{Inv} 2, \Delta \operatorname{Inv} 3$. Table 15 reports the results of regressions with the variables $\triangle T F P 1, \triangle T F P 2, \triangle T F P 3, \Delta \operatorname{Inv} 1$, $\Delta I n v 2, \Delta I n v 3$ as dependent variables, respectively.

The results show that the regression results of the core explanatory variable Num on the dependent variable in column (1) are all significantly positive, indicating that the investment in high-speed rail construction has a significant positive impact on urban productivity in the current period. The coefficient of urban productivity is positive and insignificant after one and two years of HSR construction investment and negative after three years of HSR construction investment. This finding indicates that the positive effect of HSR construction investment on productivity still exists in two years, but this effect becomes negative after three years of HSR construction investment. Also, from the results in column (5), it can be seen that the regression coefficient of the explanatory variable Num is significantly positive, indicating that there is a significant positive effect of high-speed rail construction investment on the scale of urban investment in the current period. From the regression results in columns (6-8), it can be seen that after the investment in high-speed railway construction, it has a positive effect on the scale of urban investment in the short term, but in the long term, the investment in high-speed railway construction will significantly inhibit the scale of urban investment. 


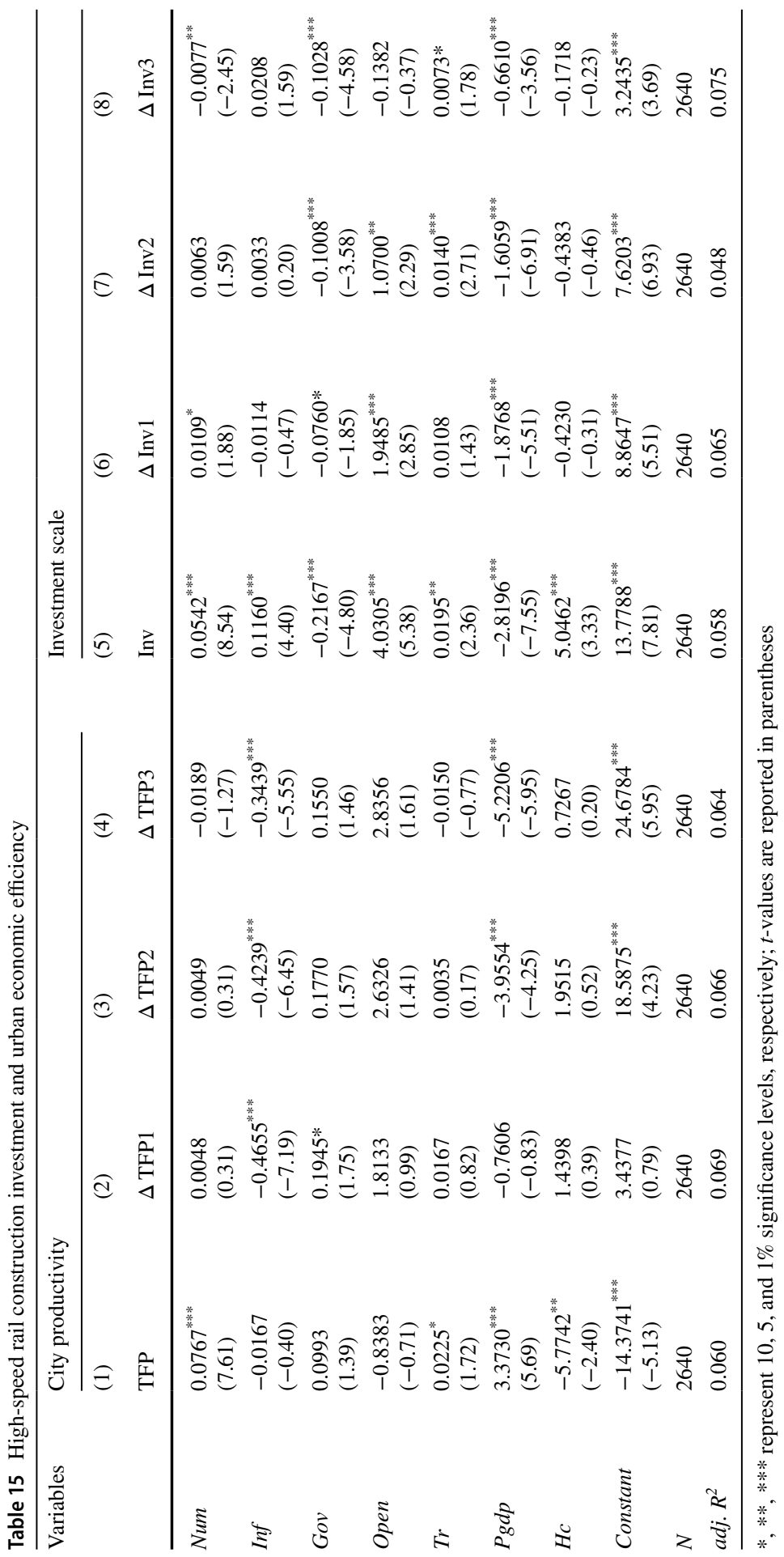




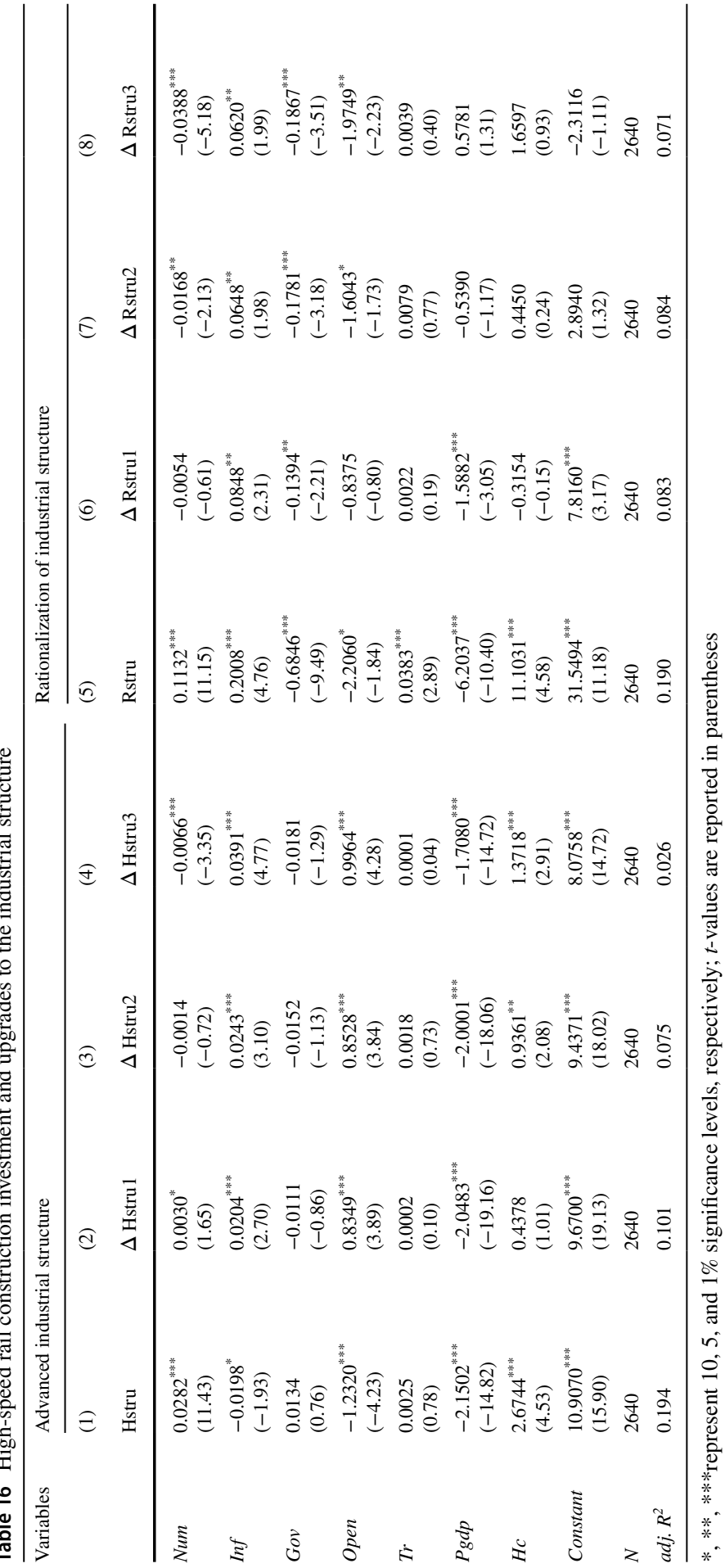


Combining the above results, Hypothesis 2 is verified. The positive impact of high-speed rail construction investment on the economy is reflected in the short term but is detrimental to economic development in the long term, which is consistent with the findings of Zhang and $\mathrm{Wu}$ (2017). Therefore, the opening of high-speed rail will change the transportation layout of cities, reduce the cost of factor mobility, accelerate the flow of technology and human resources, and enable the rational allocation of relevant resources, thus improving the economic performance of cities (Jiang et al. 2017). However, in the long run, high-speed rail investment significantly inhibits increases in the urban investment scale.

In line with the above approach, the changes in industrial structure advanced (Hstru) and industrial structure rationalization (Rstru) are used to measure the longterm economic performance of high-speed rail construction investment and calculate $\Delta H$ stru $1, \Delta H$ stru2, $\Delta H$ stru3, $\Delta$ Rstru1, $\Delta$ Rstru2, and $\Delta$ Rstru3. Table 16 reports the results of the regressions using the variables $\Delta H$ stru1, $\Delta H$ stru2, $\Delta H$ stru3, $\Delta$ Rstru1, $\Delta$ Rstru2, and $\Delta$ Rstru 3 as dependent variables. The results show that the regression results of the core explanatory variable $\mathrm{Num}$ on the dependent variable Hstru in column (1) all remain significantly positive, indicating that the investment in high-speed rail construction has a significantly positive effect on the advanced industrial structure in the current period. One year after the investment in HSR construction, the coefficient of advanced industrial structure remains significantly positive at the $10 \%$ level and is significantly negative in the third year of HSR construction investment. This shift indicates that the trend of positive effect on advanced industrial structure in the year after the investment of high-speed railway construction continues, but this effect grows negative from the second year after the opening of high-speed railway, and this negative effect becomes increasingly significant as time goes on.

The results in columns (5-8) reveal that the regression coefficient of the explanatory variable Num is significantly positive in the current period. In contrast, the coefficient is negative one year after the opening of HSR and gradually significant with the increase in time in the examination period. It indicates that opening a high-speed railway improves the industrial structure rationalization level in the short term. However, in the long term, the investment in high-speed railway construction tends to inhibit the improvement of industrial structure rationalization. With the continuous promotion of the regional development strategies in western China, the comprehensive revitalization of northeast China, the rise of central China, and the leading development of eastern China, China's economic development has made outstanding achievements. However, the unbalanced economic development of each region and the problem of its incomplete industrial infrastructure remain prominent, and the opening of high-speed rail has brought an opportunity to improve the industrial structure of each region and promote an advanced and rationalized industrial structure in the short term (Deng et al. 2020). Overall, the results in Table 16 again verify the content of Hypothesis 2. 
Table 17 High-speed rail construction investment and urban eco-efficiency

\begin{tabular}{|c|c|c|c|c|}
\hline \multirow[t]{3}{*}{ Variables } & \multicolumn{4}{|c|}{ City eco-efficiency } \\
\hline & (1) & (2) & (3) & (4) \\
\hline & GTFP & $\Delta G T F P 1$ & $\triangle G T F P 2$ & $\triangle G T F P 3$ \\
\hline Num & $\begin{array}{l}0.0019^{* * *} \\
(5.58)\end{array}$ & $\begin{array}{l}0.0003 \\
(0.72)\end{array}$ & $\begin{array}{l}0.0007^{*} \\
(1.87)\end{array}$ & $\begin{array}{l}0.0001 \\
(0.40)\end{array}$ \\
\hline $\operatorname{Inf}$ & $\begin{array}{l}-0.0012 \\
(-0.83)\end{array}$ & $\begin{array}{l}0.0020 \\
(1.04)\end{array}$ & $\begin{array}{l}0.0031^{*} \\
(1.94)\end{array}$ & $\begin{array}{l}0.0036^{* *} \\
(2.53)\end{array}$ \\
\hline Gov & $\begin{array}{l}-0.0064^{* * *} \\
(-2.62)\end{array}$ & $\begin{array}{l}-0.0023 \\
(-0.69)\end{array}$ & $\begin{array}{l}-0.0045 \\
(-1.63)\end{array}$ & $\begin{array}{l}-0.0053^{\text {** }} \\
(-2.15)\end{array}$ \\
\hline Open & $\begin{array}{l}-0.0687^{*} \\
(-1.69)\end{array}$ & $\begin{array}{l}-0.0395 \\
(-0.72)\end{array}$ & $\begin{array}{l}-0.0323 \\
(-0.71)\end{array}$ & $\begin{array}{l}-0.0657 \\
(-1.61)\end{array}$ \\
\hline $\operatorname{Tr}$ & $\begin{array}{l}-0.0002 \\
(-0.39)\end{array}$ & $\begin{array}{l}-0.0001 \\
(-0.19)\end{array}$ & $\begin{array}{l}0.0000 \\
(0.03)\end{array}$ & $\begin{array}{l}0.0002 \\
(0.35)\end{array}$ \\
\hline$P g d p$ & $\begin{array}{l}-0.0589^{* * * *} \\
(-2.90)\end{array}$ & $\begin{array}{l}-0.0768^{* * *} \\
(-2.80)\end{array}$ & $\begin{array}{l}-0.0777^{* * *} \\
(-3.41)\end{array}$ & $\begin{array}{l}-0.0748^{* * *} \\
(-3.69)\end{array}$ \\
\hline$H c$ & $\begin{array}{l}0.0516 \\
(0.63)\end{array}$ & $\begin{array}{l}0.0366 \\
(0.33)\end{array}$ & $\begin{array}{l}0.1284 \\
(1.39)\end{array}$ & $\begin{array}{l}0.1286 \\
(1.56)\end{array}$ \\
\hline Constant & $\begin{array}{l}0.2726^{\text {**** }} \\
(2.84)\end{array}$ & $\begin{array}{l}0.3647^{* * * *} \\
(2.81)\end{array}$ & $\begin{array}{l}0.3676^{\text {**** }} \\
(3.41)\end{array}$ & $\begin{array}{l}0.3557^{* * *} \\
(3.71)\end{array}$ \\
\hline$N$ & 2640 & 2640 & 2640 & 2640 \\
\hline $\operatorname{adj} . R^{2}$ & 0.048 & 0.085 & 0.072 & 0.071 \\
\hline
\end{tabular}

$*, * *, * * *$ represent 10,5 , and $1 \%$ significance levels, respectively; $t$-values are reported in parentheses

\subsection{High-speed rail construction investment and environmental benefits}

This paper uses the change in urban eco-efficiency (GTFP) to measure the environmental performance of HSR construction investment. Consistent with the above, based on the ordinary least squares (OLS) method, we use the difference in GTFP between one year before and after the occurrence of HSR construction investment $(\triangle G T F P 1)$, the difference between the mean value of gtfp two years after the occurrence of HSR construction investment and the previous year $(\triangle G T F P 2)$, and the difference between the mean value of gtfp three years after the occurrence of HSR construction investment and the previous year $(\triangle G T F P 3)$ to examine the long-term impact of HSR construction investment on the urban environment. Table 17 reports the results of the regressions with the variables $\triangle G T F P 1, \triangle G T F P 2$, and $\triangle G T F P 3$ as dependent variables, respectively.

The results show that the regression results of the core explanatory variable Num on the dependent variable in column (1) all remain significantly positive, indicating that investing in high-speed rail construction has a significantly positive impact on urban eco-efficiency in the current period. Columns (2-4) show that the coefficient of urban eco-efficiency remains positive after 1-3 years of HSR construction investment, indicating an ongoing long-term trend in the positive impact of HSR construction investment on eco-efficiency. The results in this section of the paper are consistent with most existing studies, which state that HSR construction investment 


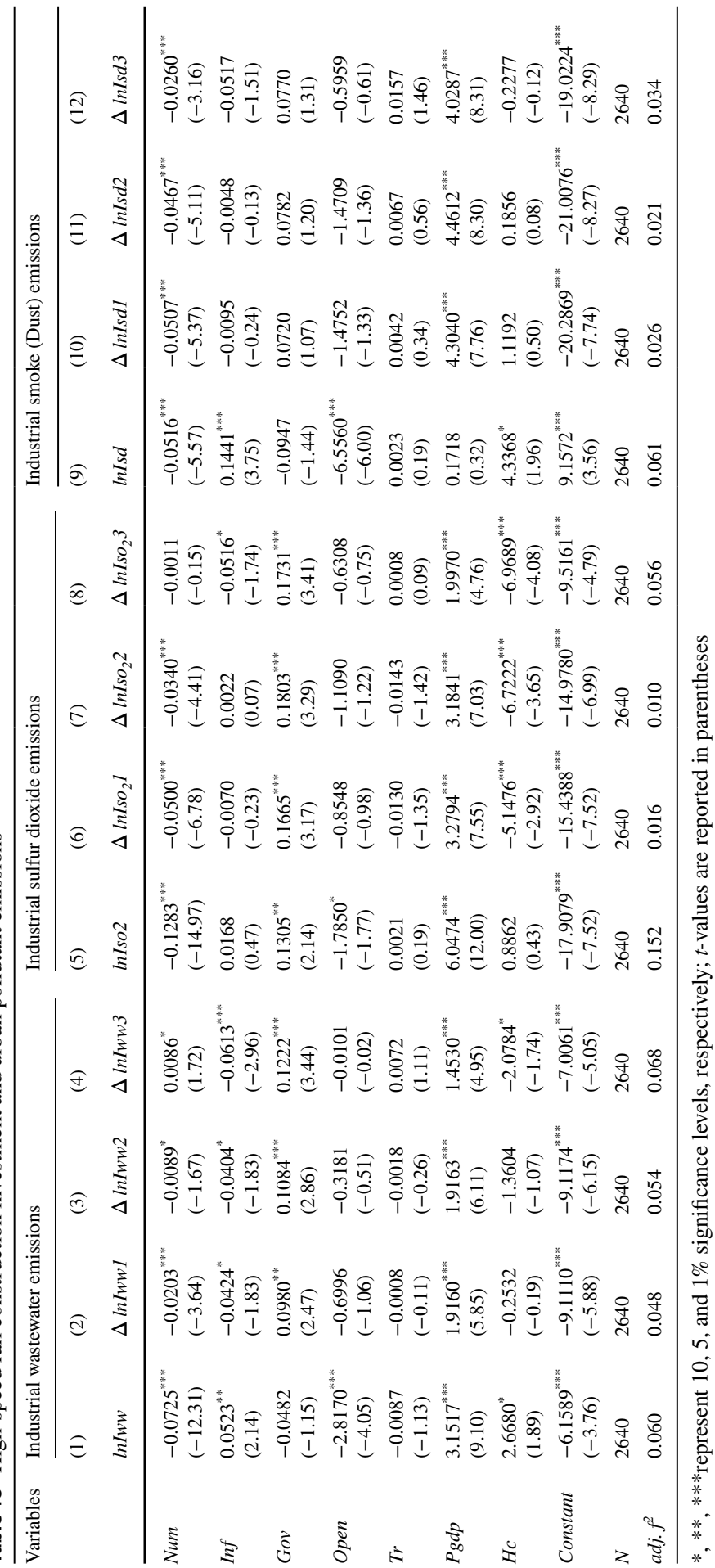


has positive externalities on urban eco-efficiency (Deng et al. 2021; Luo 2019), promoting the rational allocation of regional resources and sustainable economic development. In addition, the high-speed rail network improves urban eco-efficiency by promoting the agglomeration of service industries, and this promotion effect lasts for a more extended period.

In this paper, industrial wastewater emissions $(I w w)$, industrial sulfur dioxide emissions ( $\left.\mathrm{ISO}_{2}\right)$, and industrial smoke (Dust) emissions (Isd) are used as proxy variables to further measure the environmental benefits of high-speed rail construction investments from the perspective of pollutant emissions. Considering the unit problem, this paper calculates the difference between $I w w$ one year before and after the occurrence of high-speed rail construction $(\Delta I w w 1)$, the difference between the average value of $I w w$ of two years after construction and the previous year $(\Delta I w w 2)$, and the difference between the average value of iww three years after construction and the previous year $(\Delta I w w 3)$. We also calculate $\Delta I s o_{2} 1, \Delta I s o_{2} 2, \Delta I s o_{2} 3, \Delta I s d 1$, $\Delta I s d 2$, and $\Delta I s d 3$ using the same method.

As can be seen in Table 18, the regression results of the core explanatory variables in columns (1), (5), and (9) on the explanatory variables all remain significantly negative, indicating that the investment in high-speed rail construction has a significant inhibitory effect on urban pollutant emissions in the current period. The results in columns (2-4) show that the coefficients of the explanatory variables are still significantly negative after one to two years of high-speed rail construction investment and positive after three years of HSR investment. This finding indicates that the inhibitory effect of high-speed rail construction investment on industrial wastewater discharge remains after two years, gradually diminishing after two years. Simultaneously, high-speed rail construction investment significantly suppresses industrial sulfur dioxide and industrial smoke (Dust) emissions in the short and long term. Moreover, comparing the magnitude of the absolute values of the coefficients, it can be seen that this suppression effect persists with the increase in the time of the examination period.

The results are consistent with studies that find that urban high-speed railways generally improve environmental pollution problems (Yang et al. 2019; Zhu et al. 2019). High-speed rail effectively replaces traditional transportation by changing the preferred mode of travel. The reduction in the number of private cars in operation reduces the emission of motor vehicle pollutants and enables green travel. Therefore, the combined results of Tables 16, 17 and 18 show that Hypothesis 3 is verified.

\section{Conclusions and recommendations}

China is in a critical period of sustained and rapid economic and social development. Under the new development pattern of building a cross-promoting major domestic cycle and a dual domestic and international cycle, high-speed rail construction investment is crucial to coordinate regional development. Following the release of the "Opinions of the State Council on Reforming the Railway Investment and Financing System to Accelerate Railway Construction" in 2013, railroad investment and financing reform have achieved more noticeable results. Using city-level data 
in China from 2003 to 2018, this paper explores in depth the impact of fiscal policy on investment in high-speed railway construction using a DID model and further explores the economic and environmental benefits of high-speed railway investment.

The main conclusions obtained from this paper are as follows: first, fiscal policy helps reduce the financing cost of HSR construction projects and increases the investment scale of HSR construction. Second, the impact of fiscal policy on investment in HSR construction is heterogeneous. It varies significantly across cities with different levels of economic policy uncertainty, marketization, city characteristics, and geographic location. Specifically, the positive impact of fiscal policy on HSR construction investment is greater in cities with high economic policy uncertainty relative to those with low economic policy uncertainty and cities with a high degree of marketization relative to those with a low degree of marketization; the higher the development level of the city, the greater the impact of fiscal policy on investment in HSR construction. Additionally, the positive impact of fiscal policy on investment in HSR construction is greater in provincial capitals and port area cities; it is greater in mega-cities and super cities relative to large cities, medium cities, and small cities. Geographically, compared with the Beibu Gulf city cluster, Chengdu-Chongqing city cluster, Ha-Chang city cluster, and Beijing-Tianjin-Hebei city cluster, the positive impact of fiscal policy on high-speed railway construction investment is greater in the middle reaches of the Yangtze River city cluster, Yangtze River Delta city cluster, Central Plains city cluster, and Pearl River Delta city cluster; and the positive impact of fiscal policy on high-speed railway construction investment is more significant in the cities in central and western regions compared with the cities in eastern regions. Third, further research shows that investments in high-speed rail construction contribute positively to the scale of investment in cities in the current period. However, in the long run, high-speed rail construction significantly inhibits the increase in the urban investment scale and the development of an advanced and rationalized industrial infrastructure. Both in the short and long term, the investment in high-speed railway construction can promote the improvement of urban eco-efficiency. From the perspective of pollutant emissions, high-speed rail construction suppresses industrial wastewater, industrial sulfur dioxide, and industrial smoke (Dust) emissions. Moreover, this suppression effect is sustainable.

In order to amplify the positive influence of fiscal policy on the investment in high-speed railway construction and achieve the goal of sustainable development, this paper uses the following insights to put forward policy recommendations for the development of high-speed railway construction. First, the government should actively participate in high-speed railway construction and increase the financial and human investment in related infrastructure projects. At the same time, the government should introduce relevant policies to drive the economic growth of each region and promote the advancement and rationalization of the industrial infrastructure. On this basis, the relationship between the government and the market should be handled well to build a diversified investment and financing pattern.

Secondly, regional differences need to be considered when investing in highspeed railway construction, taking advantage of the convenience of high-speed 
railway and relying on profitable local industries for differentiated development. While the addition of high-speed rail accelerates the flow of labor and capital, it will also cause their outflow in less-developed regions. Therefore, the government needs to avoid the "siphon effect" brought by high-speed railway construction through relevant support policies and the formulation of resource allocation rules to ensure the fair allocation of road network resources.

Third, the economic benefits of high-speed railway construction should be harnessed to improve the transportation infrastructure to which it connects. Highspeed rail helps to enable all kinds of materials to quickly reach each corner of a city, optimize the allocation efficiency of resources in a particular space, share the comparative advantages of resources in various regions, and promote industrial upgrades there.

Finally, the government should make full use of the green, efficient, and convenient advantages of high-speed rail to improve urban environmental quality. The government should combine the economic construction of high-speed rail with environmental construction, improve the efficiency of environmental law enforcement, and perfect the reward and punishment system to incentivize environmental protection practices.

Acknowledgements This work was supported by the National Natural Science Foundation of China (No. 71303105), the National Social Science Foundation (No. 19FJYB039), the Postgraduate Research \& Practice Innovation Program of Jiangsu Province (NO. KYCX20_1286; No. KYCX21_1431), and the Nanjing University Innovation Program for PhD Candidates (No. CXYJ21-03). We would like to express our sincere gratitude to editors and anonymous referees for their useful comments and suggestions.

\section{References}

Ahlfeldt GM, Feddersen A (2018) From periphery to core: measuring agglomeration effects using high-speed rail. J Econ Geogr 18:355-390

Åkerman J (2011) The role of high-speed rail in mitigating climate change-The Swedish case Europabanan from a life cycle perspective. Transp Res Part D Transp Environ 16:208-217

Bai JH, Jiang FX (2015) Synergy innovation, spatial correlation and regional innovation performance. Econ Res J 50:174-187

Baker SR, Bloom N, Davis SJ (2016) Measuring economic policy uncertainty. Q J Econ 131:1593-1636

Zhang HB (2011) Research on low-carbon comparative advantages of China's high-speed railway. Macroeconomics $17-19+49$

Cai QF, Chen YH (2020) Development zone level and enterprise M\&A. China Ind Econ 6:118-136

Card D (1990) Unexpected inflation, real wages, and employment determination in union contracts. Am Econ Rev 80:669-688

Chen Y, Whalley A (2012) Green infrastructure: the effects of urban rail transit on air quality. Am Econ J Econ Policy 4:58-97

Cheng H, Wang ZQ, Peng D, Kong QX (2020) Firm's outward foreign direct investment and efficiency loss of factor price distortion: evidence from Chinese firms. Int Rev Econ Financ 67:176-188

Cheng FY (2021) Intergovernmental tax competition, trade opening and regional economic growth: an empirical study based on panel data of China's eight major urban agglomerations. Jianghan Trib $1: 34-41$

Chester MV, Ryerson MS (2014) Grand challenges for high-speed rail environmental assessment in the United States. Transp Res Part A Policy Pract 61:15-26

Chu RG (2018) Deconstruction and reconstruction of environmental innovation tax policy: from a single tool to a combination of tools. Sci Technol Prog Pol 35:107-114 
Deng TT, Wang DD, Cheng SY (2017) The impact of high speed railway on urban service industry agglomeration. J Financ Econ 43:119-132

Deng HH, Yang LX, Pan XT (2020) High-speed rail and industrial upgrading in China: facts and mechanisms. J Financ Econ 46:34-48

Deng RR, Zhang AX, Chen M (2021) Impact of high-speed rail on urban ecological efficiency in the Yangtze River economic belt: empirical analysis based on DID and SDID. East China Econ Manag 35:1-11

Fan G, Wang XL, Zhang LW, Zhu HP (2003) Marketization index for China's provinces. Econ Res J 9-18+89

Fritsch M, Slavtchev V (2011) Determinants of the efficiency of regional innovation systems. Reg Stud 45:905-918

Guo SF, Pei YL, Wu YR (2020) Research on industrial structure adjustment and upgrading effect of the development of the productive service industry. J Quant Tech Econ 37:45-62

Han J, Hayashi Y, Jia P, Yuan Q (2012) Economic effect of high-speed rail: empirical analysis of Shinkansen's impact on industrial location. J Transp Eng 138:1551-1557

Heckman JJ, Hotz VJ (1986) An investigation of the labor market earnings of Panamanian males evaluating the sources of inequality. J Hum Resour 21:507-542

Heckman JJ, Sedlacek G (1985) Heterogeneity, aggregation, and market wage functions: an empirical model of self-selection in the labor market. J Polit Econ 93:1077-1125

Hu CG, Sun JW, Wang TT (2020) Infrastructure, city size and city economic growth in megalopolis: a comprehensive analysis framework of mediating effect and moderating effect. China Soft Sci 10:85-95

Jia S, Zhou C, Qin C (2017) No difference in the effect of high-speed rail on regional economic growth based on match effect perspective? Transp Res Part A Policy Pract 106:144-157

Jiang MR, Fan Y, Xia Y et al (2017) The environmental impact and economic assessment of Chinese high speed rail investments. China Popul Environ 27:75-83

Kong Q, Guo R, Wang Y et al (2020) Home-country environment and firms' outward foreign direct investment decisions: evidence from Chinese firms. Econ Model 85:390-399

Kong QX, Chen AF, Peng D, Wong Z (2021a) Has the Belt and Road Initiative improved the quality of economic growth in China's cities? Int Rev Econ Financ 76:870-883

Kong QX, Peng D, Ni YH et al (2021b) The trade openness and economic growth quality of China: empirical analysis using ARDL model. Financ Res Lett 38:101488

Kong QX, Peng D, Zhang RJ, Wong Z (2021c) Resource misallocation, production efficiency and the outward foreign direct investment decisions of Chinese enterprises. Res Int Bus Financ 55:101343

Kong QX, Shen CR, Sun W, Shao W (2021e) KIBS import technological complexity and manufacturing value chain upgrading from a financial constraint perspective. Financ Res Lett 41:101843

Kong QX, Tong X, Peng D et al (2021f) How factor market distortions affect OFDI: an explanation based on investment propensity and productivity effects. Int Rev Econ Financ 73:459-472

Kong QX, Shen CR, Chen AF et al (2021d) How does demand scale affect services exports? Evidence from a financial development perspective. Res Int Bus Financ 58:101428

Kong Q, Shen C, Li R, Wong Z (2021g) High-speed railway opening and urban green productivity in the post-COVID-19: evidence from green finance. Glob Financ J 49:100645

Li R, Tian XH (2021) Components of government spending, structural fiscal policy and the improvement of active fiscal policy efficiency. China Ind Econ 2:42-60

Li Y, Lin XY, Fu WY (2021) The impact of high-speed rail service supply on urban labor productivity: on the threshold effect of population agglomeration and public transportation. Popul Econ 2:117-132

Liang RB, Xi PH (2016) Heterogeneous effects of rail transit on air pollution: an empirical study with RDID. China Ind Econ 3:83-98

Lin P, Meng NN (2021) Spatio-temporal differentiation and dynamic convergence of green total factor productivity growth. J Quant Tech Econ 38:104-124

Liu JH, Bai YT (2020) Research on the impact of the opening of high-speed rail on the level of marketization. Price Theory Pract 8:160-163+179

Liu YZ, Li Y (2017) High-speed rails and city economic growth in China. J Financ Res 11:18-33

Liu JL, Li XJ (2020) The reform effect, existing problems and suggestions for high quality development of China's railway industry. Theory J 2:71-82

Lu BK, Xing MY, Yang QL (2019) A measurement and spatio-temporal differences analysis of the high quality development level of China's economy. Stat Decis 35:113-117 
Luo NS, Di TM, Yang J et al (2019) Impact of the high-speed rail network on urban eco-efficiency: based on the spatial measurement of 277 prefecture-level cities nationwide. China Popul Environ 29:1-10

Nash C (2015) When to invest in high speed rail. J Rail Transp Plan Manag 5:12-22

Pan J, Zheng HL (2020) The measurement and difference analysis of the high-quality development level of the regional economy. Stat Decis 36:102-106

Puhani PA (2000) On the identification of relative wage rigidity dynamics: a proposal for a methodology on cross-section data and empirical evidence for Poland in transition. Available at SSRN 252475

Shao S, Yang LL (2010) Abundance of natural resources, dependence on resource industries and China's regional economic growth. Manage World 9:26-44

Sun GZ, Hang KN (2019) An analysis of the heterogeneous impact of the high-speed rail opening on the growth rate of total factor productivity. J Financ Econ 45:84-98

Wang C (2020) The financial multiplier of government infrastructure investment: an analysis based on the DSGE model. Financ Trade Econ 41:79-95

Wang Q, She S (2020) Green growth effect assessment of Chinese low-carbon pilot from the perspective of urban heterogeneity. Soft Sci 34:1-8

Wang YF, Ni PF (2016) Economic growth spillover and spatial optimization of high-speed railway. China Ind Econ 2:21-36

Wei W, Cao JL (2019) Research on the synergy between green credit and environmental fiscal policy. Sci Technol Prog Policy 36:21-27

Wong Z, Li RR, Zhang YD, et al (2021) Financial services, spatial agglomeration, and the quality of urban economic growth-based on an empirical analysis of 268 cities in China. Financ Res Lett 43:101993

Wu J, Nash C, Wang D (2014) Is high speed rail an appropriate solution to China's rail capacity problems? J Transp Geogr 40:100-111

Xu XC, Wang BB, Xu XF (2013) China's investment growth and its relationship with fiscal policy. Manage World 6:1-11

Yang X, Lin S, Li Y, He M (2019) Can high-speed rail reduce environmental pollution? Evidence from China. J Clean Prod 239:118135

Yuan BL, Li C (2021) Research on innovation-driven high quality economic development in China: the moderating roles of economic policy uncertainty. J Macro-Qual Res 9:45-57

Zhang HB (2011) Research on low-carbon comparative advantages of China's high-speed railway. Macroeconomics $17-19+49$

Zhang D, Guo Y (2019) Financing R\&D in Chinese private firms: business associations or political connection? Econ Model 79:247-261

Zhang DY, Vigne SA (2021) The causal effect on firm performance of China's financing-pollution emission reduction policy: firm-level evidence. J Environ Manage 279:111609

Zhang Y, Sen ZF, Zhong WB (2017c) Research on the influence of marketization on independent innovation of high-tech industry - based on quantile panel regression. J Ind Technol Econ 36:114-121

Zhang D, Guo Y, Wang Z, Chen Y (2020) The impact of US monetary policy on Chinese enterprises' R\&D investment. Financ Res Lett 35:101301

Zhang DY, Mohsin M, Rasheed AK et al (2021) Public spending and green economic growth in the BRI region: the mediating role of green finance. Energy Pol 153:112256

Zhang Y, Liu B (2009) An empirical analysis of the impact of monetary policy and fiscal policy on China's investment behavior. Financ Trade Econ 5:18-23

Zhang L, Wu XT (2017) An empirical analysis of the effect of high-speed rail on urban economic growth. Stat Decis 17:152-154

Zhang MY, Xue YZ (2020) Fiscal decentralization, infrastructure expenditure and optimal fiscal policy. Collect Essays Financ Econ 11:33-42

Zhang B, Wang YQ, Zou JX (2017) China's trade data and manufacturing industrial upgrading. Int Econ Rev 3:13-27+4

Zhang QH, Huang ZJ, Guo SF (2017) Regional economic development differences and catch-up model prediction. Stat Decis 15:146-149

Zhang MZ, Yu DH, Sun YY (2018) A study on the effects of high-speed railway on the pattern of urban population distribution. Chin J Popul Sci 5:94-108+128

Zhang D, Du P, Chen Y (2019) Can designed financial systems drive out highly polluting firms? An evaluation of an experimental economic policy. Financ Res Lett 31:218-224

Zhang WJ (2015) Does proactive fiscal policy ease a firm's financing constraints? J Cent Univ Financ Econ 10:10-15 
Zheng S, Kahn ME (2013) Understanding China's urban pollution dynamics. J Econ Lit 51:731-772

Zheng GH (2017) The effect of taxation policy consolidation on Chinese low carbon development. Public Financ Res 7:102-113

Zhou LA, Chen Y (2005) The policy effect of tax-and-fees reforms in rural China: a difference-in-differences estimation. Econ Res J 8:44-53

Zhu PF, Zhang ZY, Jiang GL (2011) Empirical study of the relationship between FDI and environmental regulation: an intergovernmental competition perspective. Econ Res J 46:133-145

Zhu SJ, Yin SS, Zhong TL (2019) Does the opening of high-speed railways inhibit urban environmental pollution? East China Econ Manag 33:52-57

Zhuang XY, Hou JW (2012) Comparative study of government investment returns between high-speed railway and highway construction: a CGE analysis. Financ Trade Econ 6:43-49

Publisher's Note Springer Nature remains neutral with regard to jurisdictional claims in published maps and institutional affiliations. 